\title{
Hypertension and Obesity
}

\author{
Ashish Aneja, ${ }^{*}$ Fadi El-Atat ${ }^{\dagger}$ Samy I. McFarlane, ${ }^{*}$ and James R. Sowers ${ }^{\mathbb{T}}$ \\ *Department of Internal Medicine, State University of New York Downstate Medical Center, \\ Brooklyn, New York 11203; 'Division of Cardiovascular Medicine, Department of Internal \\ Medicine, State University of New York Downstate Medical Center, Brooklyn, New York 11203; \\ Division of Endocrinology, Hypertension and Diabetes, Department of Internal Medicine, State \\ University of New York Downstate Medical Center, Brooklyn, New York 11203; "Department of \\ Internal Medicine, University of Missouri-Columbia, Columbia, Missouri 65212
}

\begin{abstract}
Obesity is a common problem in much of the western world today in that is linked directly with several disease processes, notably, hypertension. It is becoming clear that the adipocyte is not merely an inert organ for storage of energy but that it also secretes a host of factors that interact with each other and may result in elevated blood pressure. Of particular importance is the putative role of leptin in the causation of hypertension via an activation of the sympathetic nervous system and a direct effect on the kidneys, resulting in increased sodium reabsorption leading to hypertension. Obesity per se may have structural effects on the kidneys that may perpetuate hypertension, leading to an increased incidence of end-stage renal disease that results in further hypertension. Adipose tissue may elaborate angiotensin from its own local renin-angiotensin system. The distribution of body fat is considered important in the genesis of the obesity-hypertension syndrome, with a predominantly central distribution being particularly ominous. Weight loss is the cornerstone in the management of the obesity-hypertension syndrome. It may be achieved with diet, exercise, medications, and a combination of these measures. Anti-obesity medications that are currently undergoing clinical trials may play a promising role in the management of obesity and may also result in lowering of blood pressure. Antihypertensives are considered important components in the holistic approach to the management of this complex problem.
\end{abstract}

\section{Introduction}

Obesity is rapidly turning into an "epidemic" afflicting much of the industrialized world, resulting in a prohibitive health and economic burden on society (Mark et al., 1999a; Hall et al., 2001,2002; Sowers, 2001). A predominantly "central" or "visceral" obesity pattern triggers a myriad of cardiovascular, renal, metabolic, prothrombotic, and inflammatory responses that are essentially maladaptive, some of which constitute the "cardio-metabolic syndrome" (to be defined). These responses, individually and interdependently, lead to a substantial increase in cardiovascular disease (CVD) morbidity and mortality, including 
hypertension, coronary heart disease (CHD), congestive heart failure (CHF), sudden cardiac death (SCD), stroke, and end-stage renal disease (ESRD) (Garrison et al., 1987; Mark et al., 1999a; Zhang and Reisin, 2000; Hall et al., 2001,2002, Sowers, 2001). This review will highlight the causative role that adipose tissue may play in the genesis of hypertension, or what recently has been referred to as "obesity hypertension." Epidemiological studies have revealed a strong relation between obesity and hypertension. Data from the National Health and Nutrition Examination Survey (NHANES) (Figure 1) show a remarkable and linear relationship between rise in body mass index (BMI) and systolic, diastolic, and pulse pressures in the American population. In regression models corrected for age-related rise in blood pressure, a BMI gain of $1.7 \mathrm{~kg} / \mathrm{m}^{2}$ in men and 1.25 $\mathrm{kg} / \mathrm{m}^{2}$ in women or an increase in waist circumference of $4.5 \mathrm{~cm}$ for men and 2.5 $\mathrm{cm}$ for women corresponds to an increase in systolic blood pressure of $1 \mathrm{mmHg}$ (Kissebah and Krakower, 1994). Obesity by itself possibly accounts for $78 \%$ and $65 \%$ of essential hypertension in men and women, respectively, according to data from the Framingham Cohort (Kannel et al., 1993). Animal experiments and human studies have confirmed this causation and given insight into the mechanisms involved (Reisen et al., 1978; Alexander et al., 1979; Reaven, 1993; Carrol

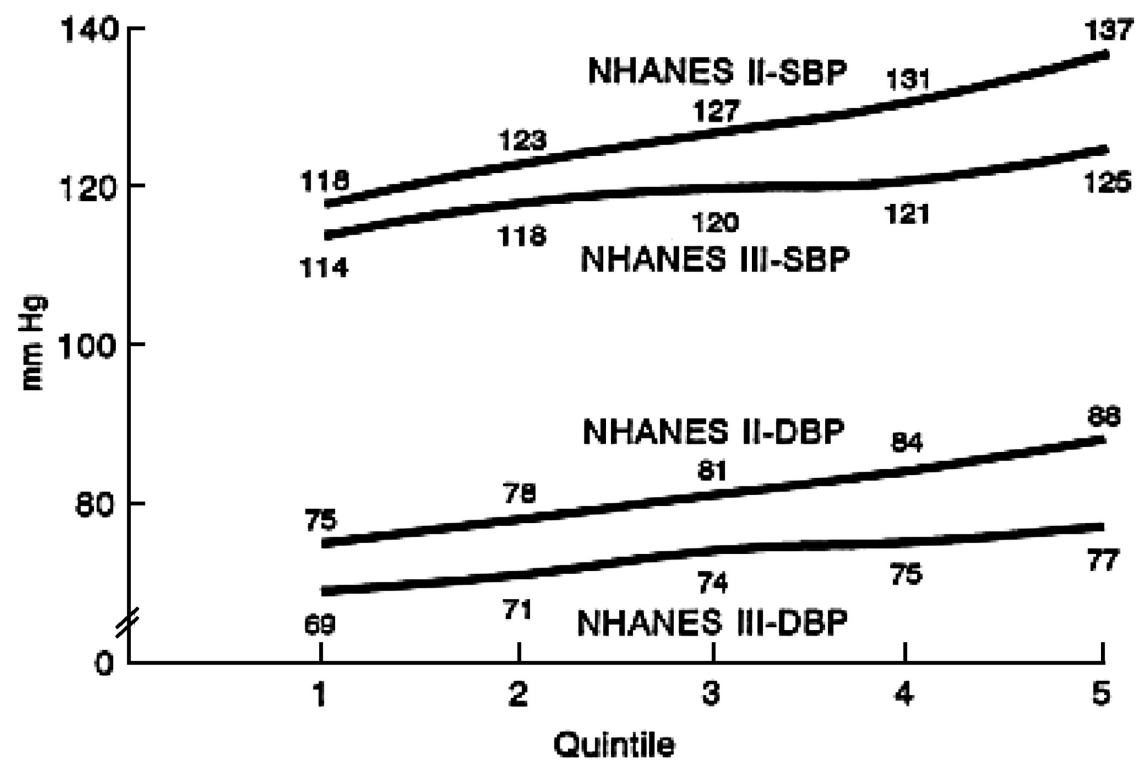

FIG. 1. Line graph shows age-adjusted systolic blood pressure (SBP) and diastolic blood pressure (DBP) from the National Health and Nutrition Examination Surveys (NHANES) II and III by NHANES III quintile of body mass index. [Source: Centers for Disease Control and Prevention, National Centers for Health Statistics.] 
et al., 1995; Van Vleit et al., 1995; Hall et al., 1996; Hall, 1997; Rocchini et al., 1999; Antic et al., 2000, Dobrian et al., 2000; Weyer et al., 2000; Rocchini, 2002). Hyperinsulinemia, hyperleptinemia, hypercortisolemia, renal dysfunction, altered vascular structure and function, enhanced sympathetic and renin-angiotensin system activity, and blunted natriuretic peptide activity stand out as major contributory mechanisms to "obesity hypertension" (Tuck et al., 1981; Rocchini et al., 1989a; Hall et al., 1993a,1996,2001,2002; Kissebah and Krakower, 1994; Cignolini et al., 1995; Mark et al., 1999a; Mansuo et al., 2000; Zhang and Reisin, 2000; Engeli and Sharma, 2001,2002).

\section{Epidemiology}

The prevalence of obesity is rapidly increasing in developing as well as industrialized countries (Mark et al., 1999a; Hall et al., 2001,2002; Sowers, 2001). Up to $61 \%$ of Americans are either overweight or obese, according to data from the 1999 census. Economic costs attributable to obesity in the United States in 2000 were estimated at $\$ 117$ billion (Garrison et al., 1987; Flegal et al., 1998; Zhang and Reisin, 2000; Sowers, 2001). Increasing obesity is common to all developed societies, particularly among children. The Nurses' Health Study involving 80,000 women revealed that a $5-\mathrm{kg}$ weight gain after age 18 was associated with a $60 \%$ higher relative risk of developing hypertension (Huang et al., 1998), compared to those women who gained $2 \mathrm{~kg}$ or less. Those who gained $10 \mathrm{~kg}$ or more increased their risk by 2.2 -fold. Similar increases have been observed in other populations (Wilsgaard et al., 2000) and in children (He et al., 2000).

Cardio-metabolic syndrome prevalence has been estimated at $22 \%$ of the U.S. population. It increases with age and varies according to ethnicity. MexicanAmericans have the highest age-adjusted prevalence (31.9\%) (Sowers, 2001). Among African-Americans and Mexican-Americans, the prevalence is nearly twice as high in women than in men $(57 \%$ and $26 \%$ higher prevalence, respectively) (Kissebah and Krakower, 1994; Cignolini et al., 1995; Hall et al., 2001,2002).

\section{Definitions}

\section{A. BODY MASS INDEX}

Overweight is defined as a BMI $>25$. (BMI is body weight in kilograms divided by the height in meters, squared, expressed as wt (in $\mathrm{kg}$ )/height $\left(\mathrm{m}^{2}\right)$.) Obesity is defined as a BMI > 30; morbid obesity is a BMI > 35 (Sowers, 2001). 


\section{B. CENTRAL OBESITY}

The distribution of weight gain is of crucial importance. A predominantly "central" pattern of weight gain, as measured by a waist-to-hip ratio, is considered more ominous from cardiovascular and glycemic standpoints because it confers a far higher risk than that expected by BMI measurements. Central obesity is often referred to as abdominal, upper-body, male-type, android, or visceral obesity vs. female-type or gynoid obesity, where there is preferential fat accumulation in the gluteal and femoral distribution (Kissebah and Krakower, 1994; Hall, 1997; Hall et al., 2001,2002; Rocchini et al., 2002). Abdominal obesity is diagnosed clinically by a waist-to-hip ratio that is $>0.95$ in men and $>$ 0.85 in women. Although clinical measures are considered acceptable in the diagnosis of true central obesity, better imaging techniques such as dual-energy X-ray absorptiometry (DEXA) or an abdominal computed tomography (CT) scan probably are required for accurate description. The pattern of obesity is important. For example, athletes such as football players often have BMIs higher than 35 , making them morbidly obese by definition. A closer look may reveal a total body fat lower than $8 \%$, quite different than the figures for those who are truly obese. Therefore, obesity defined solely by BMI may be an imperfect approximation. Clinicians must always be aware of this possible fallacy, further emphasizing the importance of the pattern of fat distribution.

\section{CARDIO-METABOLIC SYNDROME}

The presence of an interesting constellation of findings variously referred to as the cardio-metabolic syndrome, the metabolic syndrome, the deadly quartet, insulin resistance syndrome, and syndrome $\mathrm{X}$ is now an established predictor for premature and often severe CVD.

The metabolic syndrome is defined by guidelines from the National Cholesterol Education Program (Adult Treatment Panel (ATP) III). These guidelines suggest that the clinical identification of the metabolic syndrome be based upon the presence of any three of the following: 1) abdominal obesity, defined as a waist circumference in men $>102 \mathrm{~cm}$ (40 inches) and in women $>88 \mathrm{~cm}$ (35 inches) (it was noted by ATPIII that some men with lower waist circumference (i.e., 94-102 cm) may develop insulin resistance due to genetic factors); 2) triglycerides $\geq 150 \mathrm{mg} / \mathrm{dL}(1.7 \mathrm{mmol} / \mathrm{L}) ; 3$ ) high-density lipoprotein (HDL) cholesterol $<40 \mathrm{mg} / \mathrm{dL}(1 \mathrm{mmol} / \mathrm{L})$ in $\mathrm{men}$ and $<50 \mathrm{mg} / \mathrm{dL}(1.3 \mathrm{mmol} / \mathrm{L})$ in women; 4) blood pressure $\geq 130 / \geq 85 \mathrm{mmHg}$; or 5) fasting glucose $\geq 110 \mathrm{mg} / \mathrm{dL}$ (6.1 mmol/L) (National Institutes of Health, 1998).

The World Health Organization (WHO) has proposed a different definition for the metabolic syndrome. A diagnosis of the metabolic syndrome required the presence of either hyperinsulinemia or a fasting plasma glucose $\geq 110 \mathrm{mg} / \mathrm{dl}(6.1$ $\mathrm{mmol} / \mathrm{L}$ ) and an additional two characteristics from among the following: 1) 
abdominal obesity, defined as a waist-to-hip ratio $>0.90$, a BMI $\geq 30 \mathrm{~kg} / \mathrm{m}^{2}$, or a waist girth $\geq 94 \mathrm{~cm}$ (37 inches); 2) dyslipidemia, defined as serum triglyceride $\geq 150 \mathrm{mg} / \mathrm{dL}(1.7 \mathrm{mmol} / \mathrm{L})$ or HDL cholesterol $<35 \mathrm{mg} / \mathrm{dL}(0.9 \mathrm{mmol} / \mathrm{L})$; or 3) blood pressure $\geq 140 / 90 \mathrm{mmHg}$ or the administration of antihypertensive drugs.

\section{Alterations in Renal Function and Structure, Leading to Obesity-related Hypertension}

\section{A. RENAL HEMODYNAMIC CHANGES}

A high-fat diet consistently results in enhanced sodium reabsorption by the kidneys (Figure 2). Interestingly, weight loss in the same individual promotes urinary sodium excretion (Figure 3), demonstrating a direct link between BMI and sodium retention (Tuck et al., 1981; Lucas et al., 1985; Reaven and Hoffman, 1987; Landsberg and Krieger, 1989; Rocchini et al., 1989a; Tuck, 1992; Reisin et al., 1993; Baron et al., 1995; Kassab et al., 1995; Hall et al., 1996,1999a; Sugarman et al., 1997; Bloomfield et al., 2000; Stern et al., 2001; U.S. Renal Data System, 2001). Obesity is associated with activation of the renin-angiotensin system (RAS) (Tuck, 1992; Zhang and Reisin, 2000; Hall et al., 2001,2002), increased sympathetic nervous system (SNS) activity (Landsberg and Krieger, 1989; Carrol et al., 1995; Mark et al., 1999a; Weyer et al.,

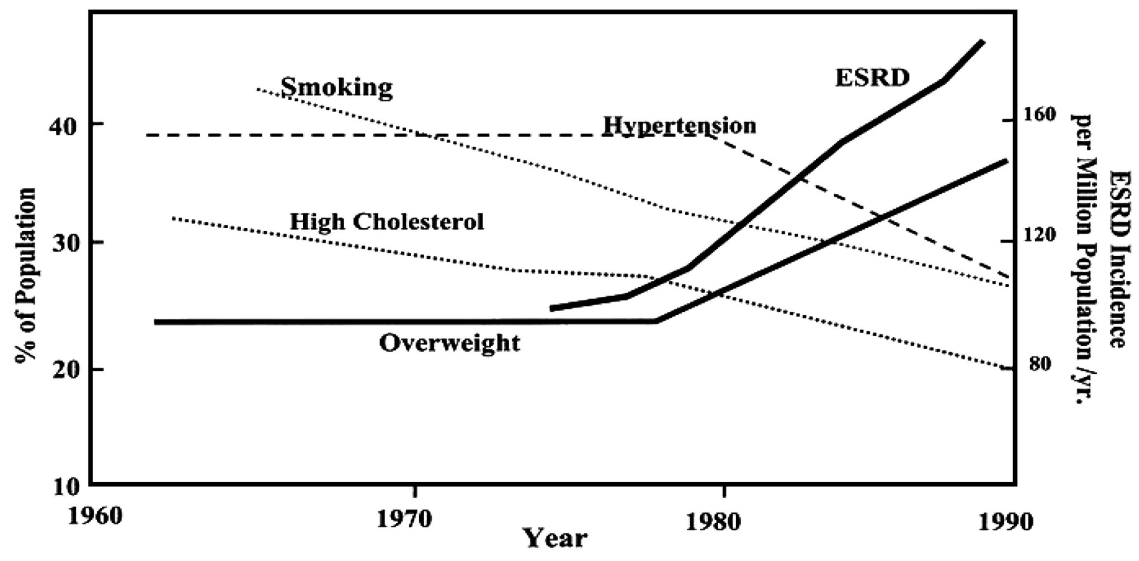

FIG. 2. Estimated prevalence of cardiovascular risk factors, as assessed by NHANES I and II and NHANES II incidence of end-stage renal disease (ESRD) reported by the United States Renal Data Systems Surveys. [Reprinted with permission from Hall JE, Brands MW, Dixon WN, Smith MJ Jr 1993 Obesity-induced hypertension: renal function and systemic hemodynamics. Hypertension 22:292-299. Copyright Lippincott Williams \& Wilkins.] 


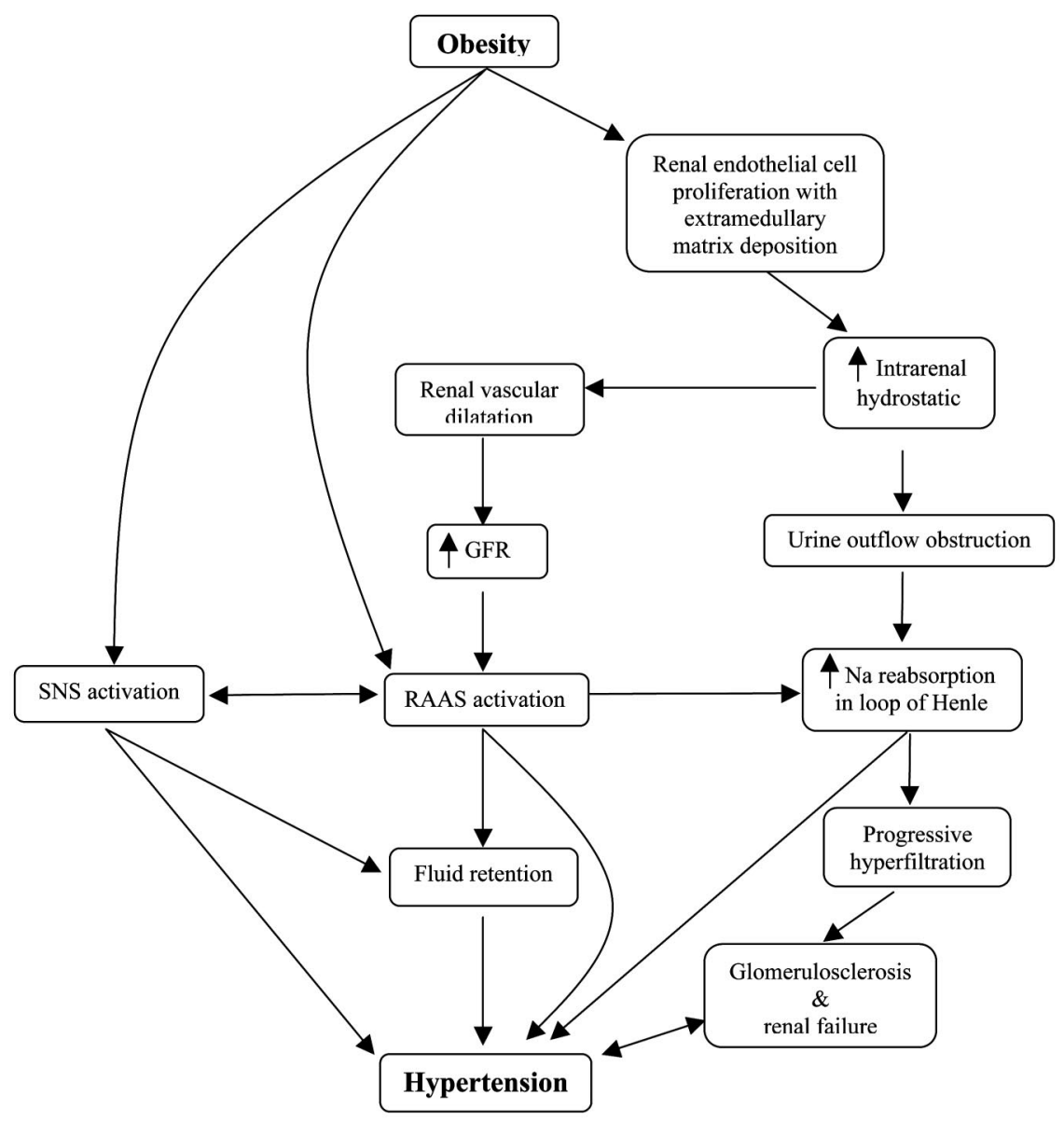

FIG. 3. Mechanisms responsible for progressive renal failure in obesity hypertension. Structural and functional alterations in the kidneys collaborate, resulting in activation of the sympathetic nervous system (SNS) and the renin-angiotensin aldosterone system (RAAS), leading to fluid retention. Once ESRD develops, it perpetuates hypertension. Abbreviations: GFR, glomerular filtration rate; $\mathrm{Na}$, sodium. [Reprinted with permission from Rocchini AP, Key J, Bordie D, et al. 1989 The effect of weight loss on the sensitivity of blood pressure to sodium in obese adolescents. N Engl J Med 321:580-585. Copyright 1989 The Massachusetts Medical Society.]

2000; Abate et al., 2001; Hall et al., 2001), and hyperinsulinemia (Reaven, 1993; Weyer et al., 2000), all of which may contribute to sodium reabsorption and associated fluid retention and may therefore contribute to renal obesity hypertension (Reisen et al., 1993; Burt et al., 1995; Hall et al., 1999b; Engeli and Sharma, 2001; Stern et al., 2001). A compensatory lowered renal vascular 
resistance, elevated kidney plasma flow, increased glomerular filtration rate, and the higher blood pressure associated with obesity are important in overcoming increased sodium reabsorption. Neurohumoral factors like angiotensin II (AII), sympathetic system, and cytokines — either individually or synergistically — are involved in these compensatory mechanisms. In obese hypertensives, an inappropriately small natriuretic response to a saline load at mean arterial or intraglomerular pressure is seen and is often referred to as impaired pressure natriuresis (Figure 3) (Kassab et al., 1995; Hall et al., 1996; Hall, 1997; Engeli and Sharma, 2001). These adaptive changes increase glomerular wall stress and, especially in the presence of other risk factors such as hyperlipidemia and hyperglycemia, may provoke glomerulosclerosis, proteinuria, microalbuminuria, and loss of nephron function in the "obese" kidney, even before structural microscopic changes are evident. The combination of these potentially nephrotoxic mechanisms, including hyperfiltration and hypertension, may initiate and, indeed, perpetuate renal damage. The early glomerular hyperfiltration in obesity is often as great as that observed in uncontrolled type I diabetes.

\section{B. RENAL STRUCTURAL CHANGES}

Altered intrarenal physical forces are believed to play a role in sodium retention, mainly by slowing down the tubular flow rate (Weisinger et al., 1974; Reisen et al., 1984; Wesson et al., 1985; Arnold et al., 1994; Hall, 1994; Alonso-Galicia et al., 1995; Bruzzi et al., 1997; Sugarman et al., 1997; Hall et al., 1998; Bloomfield et al., 2000; Henegar et al., 2001; Kambham et al., 2001; Okosun et al., 2001; Sundquist et al., 2001). Observations from obese animals and humans have shown an increase in renal weight attributable to endothelial cell proliferation and intrarenal lipid and hyalouronate deposition in the matrix and inner medulla. These depositions in the tightly encapsulated kidney lead to distortion of the intrarenal mechanical forces. The interstitial fluid hydrostatic pressure is elevated to $19 \mathrm{mmHg}$ in obese dogs, compared to $9-10 \mathrm{mmHg}$ in lean dogs. This increase in pressure and volume causes parenchymal prolapse and urine outflow obstruction, resulting in slow intrarenal flow and increased sodium reabsorption. Of particular importance is the increased sodium reabsorption in the loop of Henle, which leads to a feedback-mediated renal vascular dilation, elevation of glomular filtration rate (GFR), and stimulation of the renin-angiotensin aldosterone system (RAAS), despite volume expansion overcoming the increased tubular reabsorption and maintaining sodium balance. However, persistent glomerular hyperfiltration - in combination with glucose intolerance, hyperlipidemia, and hypertension - results ultimately in glomerulosclerosis and renal failure.

The structural changes occurring in the human kidney as a consequence of obesity have been demonstrated in a large retrospective human study that 
incorporated 6800 renal biopsies. Obesity was associated with a peculiar obesityrelated glomerulopathy, defined as focal segmental glomerulosclerosis associated with enlargement of the glomerulus itself. The mean BMI in these patients was $41.7 \mathrm{~kg} / \mathrm{m}^{2}$. Compared with the idiopathic variety, obesity-associated focal segmental glomerulosclerosis had lower rates of nephrotic syndrome, fewer lesions of segmental sclerosis, and a greater glomerular size. The disease course in this population was dictated largely by the presence of co-morbid conditions such as hypertension and dyslipidemia. A recent study of the German WHO MONICA (Monitoring of Trends and Determinants in Cardiovascular Disease) Augsberg study population found a steady increase in the presence of microalbuminuria, an early marker of renal vascular damage with quintiles of waist-to-hip ratio. In this study, the odds ratio for the development of microalbuminuria for individuals with central obesity was not very different from that for patients with hypertension. Thus, over a span of time, obesity by itself may perpetuate hypertension by these structural damages.

The parallel increase in the prevalence of obesity and ESRD (Figure 4), in addition to the close association between obesity and type II diabetes and hypertension that are the two major risks of ESRD, has led to speculation that obesity may account for at least half of ESRD in the United States.

In summary, persistent obesity causes renal injury and functional nephron loss, contributing to elevated blood pressure, which in turn leads to further renal injury, thereby setting off a vicious circle of events leading to further elevated BP and renal injury. Interestingly enough, it is difficult to dissociate the cause from the effect in this circle, since the overall burden of obesity may be strongly time dependent (Figure 4).

\section{Role of SNS, Biochemical, Neurochemical, and Hormonal Mediators}

\section{A. SYMPATHETIC NERVOUS SYSTEM}

Several mechanisms and mediators have been postulated as causative in the genesis of adrenergic overactivity in the obese (Hall et al., 1993b; Grassi et al., 1995,1998; Rumantir et al., 1999; Esler, 2000; Mansuo et al., 2000; Weyer et al., 2000). Notable are elevated insulin levels with insulin resistance; activation of renal afferent nerves that, in turn, are stimulated by increased intrarenal pressures, leading to the subsequent activation of renal mechanoreceptors; plasma free fatty acids (FFAs); angiotensin II; elevated leptin levels; potentiation of central chemoreceptor sensitivity; and impaired baroreflex sensitivity.

There are several reasons to believe that SNS activation may contribute significantly to the obesity-hypertension syndrome. Obese subjects have elevated sympathetic activity, measured both directly and indirectly. A diet that results in obesity has been found to increase baseline plasma norepinephrine levels, to 


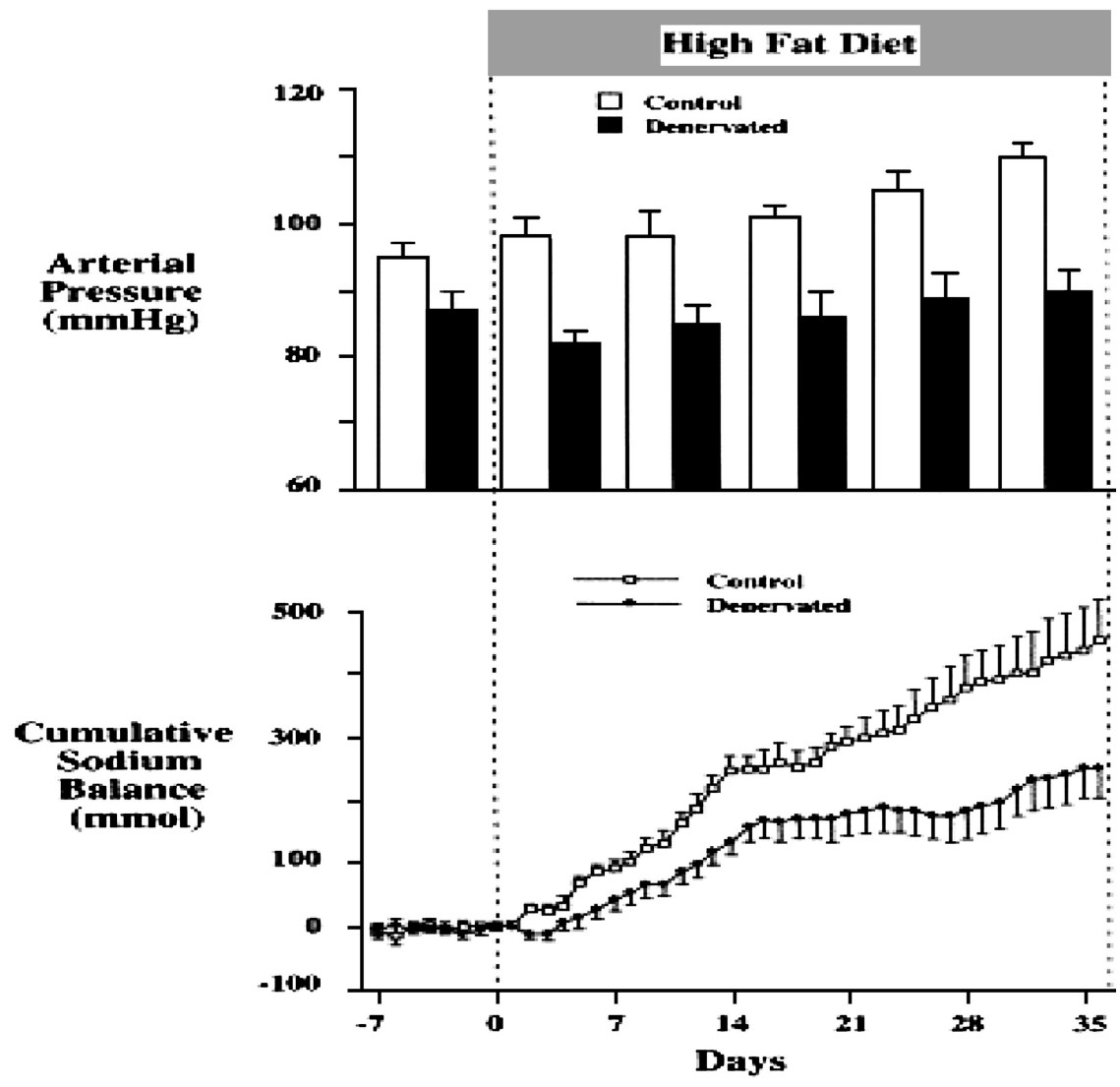

FIG. 4. Effects of 5 weeks of a high-fat diet on mean arterial pressure and cumulative sodium balance in dogs with innervated kidneys (control) and bilaterally denervated kidneys (denervated). [Reprinted with permission from Kassab S, Kato T, Wilkins C, Chen R, Hall JE, Granger JP 1995 Renal denervation attenuates the sodium retention and hypertension associated with obesity. Hypertension 25:893-897.]

amplify the SNS response to stimuli such as handgrip and upright posture, and to increase catecholamine turnover in peripheral tissues. In addition to elevated renal sympathetic activity, muscle sympathetic activity is elevated in obese hypertensive subjects, when measured with microneurographic methods (Grassi et al., 1998). Weight loss, on the other hand, reduces sympathetic activity, which further supports this hypothesis. Interestingly, Pima Indians do not demonstrate a markedly increased sympathetic tone when obese and also do not get hypertensive to the same degree as other racial groups. Also, medications that abolish or diminish the central sympathetic drive cause a greater blood pressure reduc- 
tion in obese as compared to lean subjects (Hildebrandt et al., 1993; Licata et al., 1994a; Wofford et al., 2001). Indeed, in dogs fed a high-calorie diet, a combined blockade of $\alpha$ and $\beta$ receptors lowered blood pressure more significantly in obese than in lean dogs. Clonidine, which blocks central $\alpha 2$ receptors and thereby markedly reduces the central sympathetic drive, blunts hypertension in dogs fed a high-calorie diet. Similar results have been observed in humans. To further support the hypothesis, sympathetic denervation of the kidneys has a significant negative effect on renal sodium retention and thereby on obesity hypertension. In dogs fed a high-fat diet, renal nerves appear crucially important for sodium retention and hypertension. In dogs with denervated kidneys, sodium retention was markedly attenuated, leading to a lower blood pressure. Therefore, it appears that renal nerves play a pivotal role in salt retention, impaired pressure natriuresis, and hypertension.

\section{B. INSULIN RESISTANCE AND HYPERINSULINEMIA}

Hyperinsulinemia was considered a key factor governing obesity-induced hypertension in the recent past. It is well known that obese subjects have markedly elevated insulin levels, which are required to maintain glucose and fatty acid metabolism, and often are resistant to the actions of insulin on peripheral tissues (DeFronzo et al., 1975; Rocchini et al., 1990,1996; Hall et al., 1993b; Bjorntorp and Rosmond, 2000). This resistance to insulin is not universal to all tissues; some tissues retain their sensitivity to its effects, referred to as selective insulin resistance. Studies in the acute setting suggest that insulin may contribute to sodium retention and sympathetic activity and therefore to hypertension (Rocchini et al., 1987,1989b). However, on further investigation, elevated insulin levels in both acute and chronic settings have not been found to affect salt excretion, sympathetic activity, and blood pressure in humans and dogs (Hall et al., 1986,1995; Hildebrandt et al., 1999a). In fact, infusions to raise insulin levels to match those found in the obese actually lower blood pressure, suggesting a dominant depressor effect for insulin. Even in obese dogs resistant to the metabolic effects of insulin, infusions did not have a pressor effect. A central nervous system (CNS) infusion of insulin did not demonstrate a change in blood pressure in the dog.

In rats, however, hyperinsulinemia does elevate blood pressure. The underlying mechanisms are probably mediated by a complex interaction between insulin, the RAAS, and thromboxane (TXA2) activity. This hypothesis was further tested when blockade of RAAS or TXA2 abolished the blood pressure rise (Brands et al., 1997; Keen et al., 1997; Sechi, 1999). It therefore appears that the initial enthusiasm generated by rodent studies in hyperinsulinemia as causative for hypertension in the obese may not be extrapolated to humans. 
However, some researchers believe that insulin resistance plays a part in blood pressure regulation. This association, although controversial, is based upon the following hypotheses. There is evidence that insulin-mediated vasodilatation is impaired in an insulin-resistant state, which may lead to hypertension (Laasko et al., 1990). In healthy subjects, insulin infusions stimulate endothelin-1 and nitric oxide (NO) activity (Cardillo et al., 2000). In subjects who have developed hypertension, reduced insulin-mediated vasodilatation is associated with reduced endothelial NO production. Also, insulin increases renal sodium reabsorption (Gupta et al., 1992). Obese individuals tend to have glomerular hyperfiltration and these increased filtration rates correlate well with fasting insulin levels (Ribstein et al., 1995). A class of drugs called thiazolidinediones that are insulin sensitizers has been shown to have antihypertensive properties in rats and humans. It has been demonstrated that troglitazone significantly reduced both systolic and diastolic blood pressures, as assessed by 24-hour blood pressure monitoring in normotensive, insulin-resistant human subjects associated with improved insulin sensitivity and glucose tolerance (Nolan et al., 1994).

\section{RESISTIN}

Resistin is a newly discovered signaling protein that probably plays an important role in the development of insulin resistance and is thought to be the missing link between obesity and diabetes. The role of resistin in hypertension is being researched. A recent study from China reported that resistin gene polymorphism is an independent factor associated with systolic and diastolic blood pressures in type 2 diabetics. Diabetics with the GG genotype were found to have a higher prevalence of hypertension in this population (Tan et al., 2003). Other reports in Caucasian and Japanese populations found no association between resistin gene polymorphism and type 2 diabetes but the single nucleotide polymorphism (SNP) in the promoter region was a significant predictor of the insulin-sensitivity index. It was therefore hypothesized that noncoding SNPs in the resistin gene might influence insulin sensitivity in interaction with obesity.

\section{FREE FATTY ACIDS}

High FFA levels are thought to raise blood pressure by increasing sympathetic activity or enhancing the sympathetic vascular responses (Stepniakowski et al., 1995; Grekin et al., 1997). Subjects with visceral obesity deliver a FFA load to the liver that, in turn, activates hepatic afferent pathways that may lead to sympathetic activation and contribute to insulin resistance (Bergman et al., 2001). FFA levels in obese subjects are approximately 2 -fold higher than in lean subjects. Also, an acute rise in FFA levels induced by intralipid infusion increases vascular reactivity to $\alpha$-adrenergic agonists. They may also enhance reflex vasoconstrictor responses in the peripheral circulation. Infusions of oleic 
acid into the portal of systemic circulation in rats increased their blood pressure and heart rates. These effects were abolished by adrenergic blockade. Interestingly, however, portal vein infusion caused a greater blood pressure rise than systemic infusions, emphasizing the potential role of afferent pathways in the liver. In humans, high rates of intralipid and heparin infusion caused a small (i.e., $4 \mathrm{mmHg}$ ) increase in mean blood pressure (Steinberg et al., 1997). On the other hand, long-term effects of FFAs on blood pressure are less clear and warrant further investigation (Hildebrandt et al., 1999b). In dogs, infusion of long-chain fatty acids had no effect on blood pressure, in contrast to rats that demonstrated a rise in blood pressure and heart rate. Neither cerebral (via vertebral artery) nor systemic infusion of long-chain fatty acids in dogs has a significant effect on arterial pressure, renal function, or hemodynamic responses. Therefore, the relationship between elevated FFA levels and hypertension currently is tenuous at best and merits further investigation.

\section{E. LEPTIN}

Leptin is a 167-amino acid peptide that has been the subject of intense research and discussion in recent years due to its possible role in the obesityhypertension syndrome. Figure 5 schematically demonstrates the possible mechanisms via which leptin may exert its pressor effects (Zhjang et al., 1994; Pellymounter et al., 1995; Lee et al., 1996; Haynes et al., 1997,1998a; Casto et al., 1998; Flier, 1998; Lu et al., 1998; Onions et al., 1998; Shek et al., 1998; Hall et al., 1999b; Mark et al., 1999b; Lembo et al., 2000; Rahmouni et al., 2001; Carlyle et al., 2002). It is secreted by white adipocytes (Maffei et al., 1995; Considine, 2001). Leptin levels correlate well with the body adipose tissue stores. Levels of 5-15 $\mu \mathrm{g} / \mathrm{ml}$ are noted in lean individuals and are typically elevated in most obese subjects (Considine et al., 1996). It crosses the blood-brain barrier to the CNS via a saturable, transport-mediated endocytosis, where it binds to its receptors $(\mathrm{Ob}-\mathrm{R})$ in the lateral and medial regions of the hypothalamus (Golden et al., 1997). The Ob-Rb is a full-length receptor with a transmembrane domain and a long intracellular carboxyl-terminal tail. The Ob-Ra, Ob-Rc, and Ob-Rd are prematurely terminated receptor proteins with short intracellular tails. The Ob-Re lacks the transmembrane domain and thus may function as a soluble receptor to bind and inactivate the circulating leptin. This binding of leptin to its receptor triggers a series of reactions and neuropeptide pathways that serve to regulate energy balance by reducing appetite and increasing energy expenditure via stimulation of the adrenergic system (McAuley et al., 1993; Thornton et al., 1994; Fan et al., 1997; Huszar et al., 1997; Haynes et al., 1999). Evidence for the fact that leptin acts as a feedback inhibitor of food intake and regulates body weight comes from genetic studies in mice and humans. Mice that lack the ability to synthesize leptin (i.e., ob/ob mice) or that have mutations of the leptin receptor 


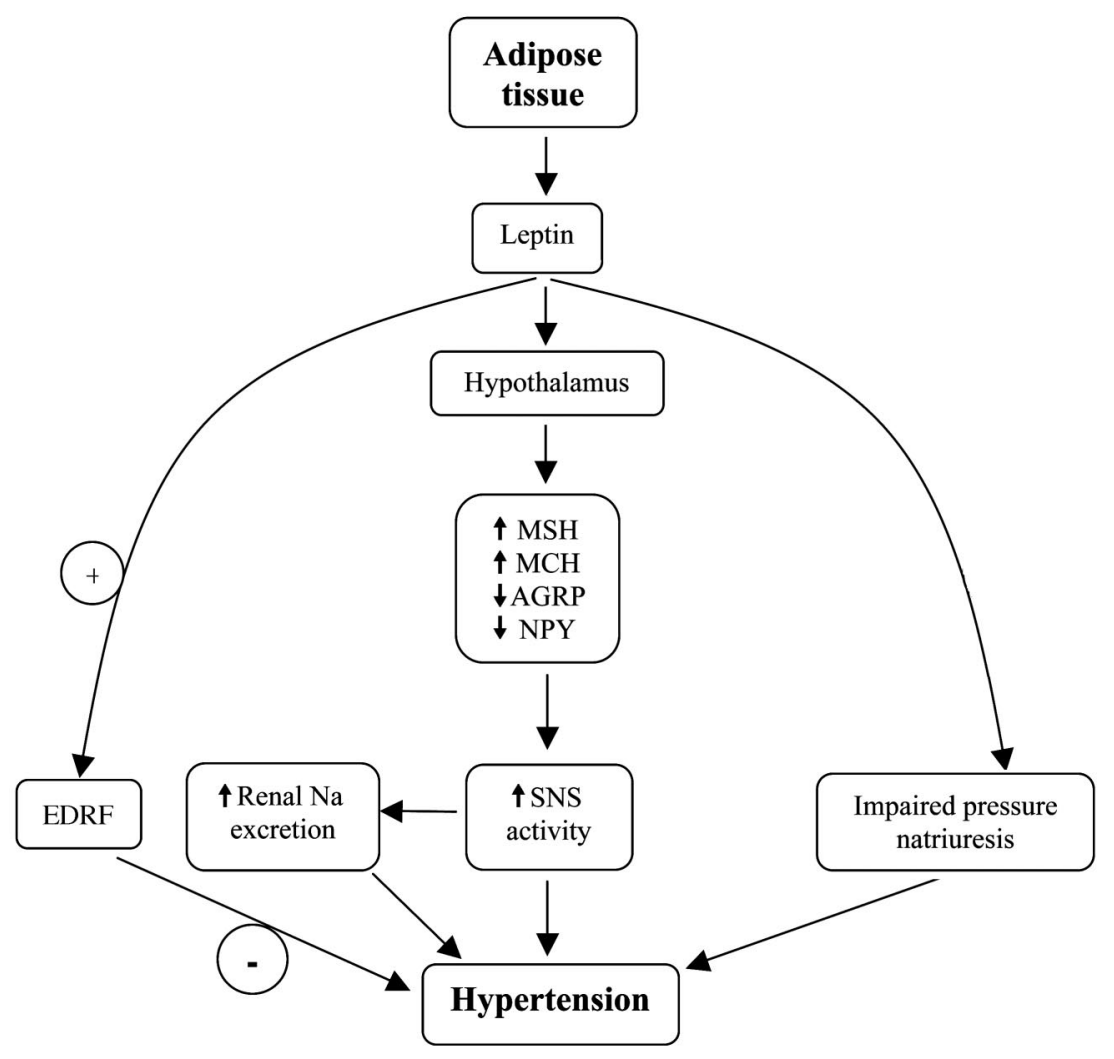

FIG. 5. A summary of the interactions through which leptin is thought to contribute to hypertension. Abbreviations: $\alpha$-MSH, $\alpha$-melanocyte-stimulating hormone; $\mathrm{MCH}$, melanin-concentrating hormone; AGRP, agouti-related peptide; NPY, neuropeptide Y; EDRF, endothelium-derived relaxing factor; SNS, sympathetic nervous system; $\mathrm{Na}$, sodium.

(i.e., db/db mice) develop extreme obesity. Mutations of the leptin gene in humans result in extreme obesity but are very rare and do not contribute significantly to the obesity epidemic.

Several rodent studies have indicated that intravenous (IV) and intracerebroventricular (ICV) infusion of leptin increases sympathetic activity in kidneys, adrenals, and brown adipose tissue (BAT) after 2-3 hours of infusion (Figure 6) (Shek et al., 1999; Aizawa-Abe et al., 2000). Leptin infusion in rodents causes mild acute blood pressure elevation, whereas long-term infusions cause a more-significant and sustained rise (Haynes et al., 1998b; Mark et al., 1999b). Failure of blood pressure to rise significantly in the acute scenario may be explained by a concomitant stimulation of NO synthesis, which, in turn, coun- 


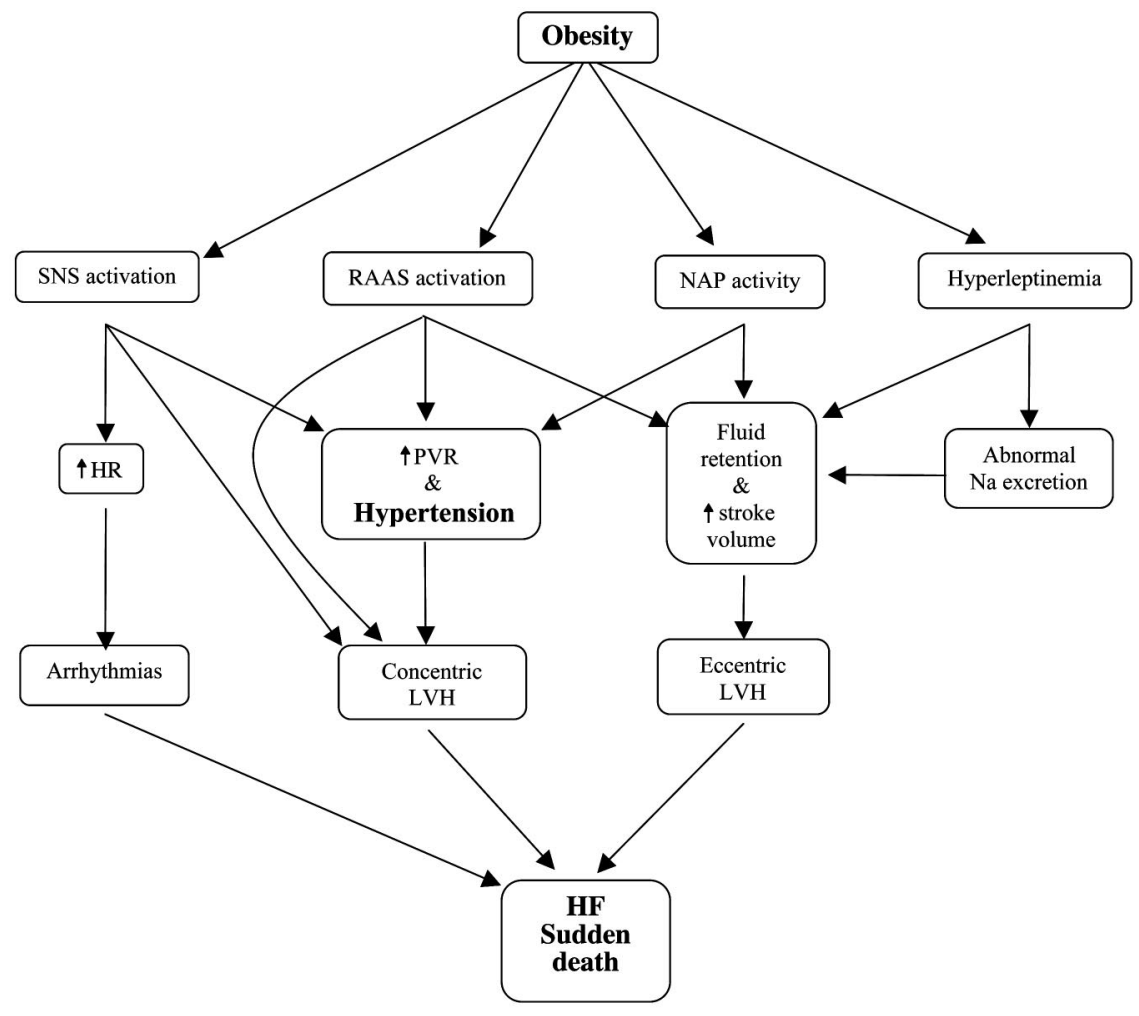

FIG. 6. A summary of the mechanisms by which obesity may lead to excessive cardiovascular morbidity and mortality. Abbreviations: SNS, sympathetic nervous system; RAAS, renin-angiotensin aldosterone system; NAP, natriuretic peptide; HR, heart rate; PVR, peripheral vascular resistance; $\mathrm{Na}$, sodium; LVH, left ventricular hypertrophy; HF, heart failure; $\uparrow$, increase.

teracts its pressor effects (Hirose et al., 1998; Suter et al., 1998; Frubeck, 1999; Lembo et al., 2000; Kuo et al., 2001). An alternative explanation is that leptin's sympathetic effect on peripheral vasoconstriction is probably not potent enough to produce significant blood pressure elevation, while the main leptin pressor effect is via the SNS, causing avid renal salt retention and hence hypertension. The rise in blood pressure with leptin infusion is slow in onset and occurs despite a reduction in food intake that accompanies it that would tend to reduce blood pressure. Moreover, the hypertensive effects of leptin are amplified when NO synthesis is impaired experimentally. Conceivably, NO production in the obese is impaired due to endothelial dysfunction.

Transgenic mice that overexpress leptin have elevated blood pressure levels comparable to those produced by leptin infusions. Importantly these chronic 
blood pressure elevations are abolished completely by $\alpha$ and $\beta$-adrenergic blockade (Shek et al., 1999; El-Haschimi et al., 2000). Also, obese mice that are leptin deficient and obese rats with a leptin receptor mutation usually do not have elevated blood pressure, compared with lean control mice. This suggests that hyperleptinemia with normally functioning leptin receptors is crucial for leptininduced hypertension (VanHeek et al., 1997; Ishizuka et al., 1998). The role of minor differences in the production and sensitivity to leptin towards contributing to obesity is less well understood.

Women typically have higher leptin levels than men (Flier, 1998) but these differences may not be accountable by fat mass alone. The effect of ethnicity on leptin levels is even less well understood. Blacks may have higher leptin concentrations than whites, even when adjusted for fat volume. Another important concept that has gained ground is the presence of selective leptin resistance (El-Haschimi et al., 2000). Obese humans continue to overeat, despite elevated circulating leptin levels, indicating a failure of feedback mechanisms on satiety. Yet they develop hypertension, indicating that the effect of leptin on the sympathetic system is intact. As attractive as this hypothesis may sound, it has been tested only in rodents and not in humans (VanHeek et al., 1997). The complexity of the relationship between adiposity, leptin, and long-term blood pressure control is further illustrated by the fact that lower body obesity causes greater increases in leptin than visceral obesity, even though visceral obesity is more closely associated with hypertension.

\section{Role of Neuropeptide Y, Melanocortin-4 Receptors, and Other Neurochemicals}

Activation of leptin receptors in the arcuate nucleus initiates a cascade of downstream events. These include inhibition of neurons containing neuropeptide $\mathrm{Y}$ (NPY), an orexigenic peptide, and stimulation of neurons containing proopiomelanocortin (POMC), the precursor of $\alpha$-melanocyte-stimulating hormone (MSH), an anorexigenic peptide. NPY is a potent and effective orexigenic agent upon acute and chronic administration. Chronic ICV infusion of NPY in rats produces an obesity syndrome. It has been postulated that endogenous NPY may have an important role in basal and starvation-induced food intake. However the receptor subtype that mediates the orexigenic effects of NPY is unknown. The negative effect of leptin on NPY formation in the hypothalamus is thought to be the primary mediator causing appetite suppression. NPY injections into the thalamus reproduce all features of hypoleptinemia (e.g., obesity, excessive eating behavior, decreased BAT heat production) (Mountjoy et al., 1994; Boston et al., 1997; Huszar et al., 1997; Seeley et al., 1997; Haynes et al., 1998a; Vaisse et al., 1998; Yeo et al., 1998). The ob/ob phenotype in ob/ob mice appears to be mediated, in part, by increased NPY because ob/ob mice in which NPY 
expression has been knocked out (NPY ${ }^{-} / \mathrm{NPY}^{-}$) are substantially less obese than ob/ob mice with normal NPY expression. However, obesity in these mice is severe, even in the absence of NPY expression, and they respond normally to the satiety effects of leptin, indicating that leptin must act on other targets to induce satiety. The administration of NPY into the vagal nucleus of tractus solitarius or caudal ventrolateral medulla causes a reduction in blood pressure (Schorr et al., 1998). Since hyperleptinemia causes a reduction in brain NPY levels, it is possible that the hypertensive effects of leptin may be mediated by a reduction in NPY levels. At present, there is little evidence regarding the putative role of reduced central levels of NPY in mediating the effects of leptin on sympathetic activity and arterial pressure.

The POMC pathway may interact with leptin to stimulate sympathetic activity and regulate energy balance. MC4-R may play an important role in feeding mechanisms. While the central administration of MC4-R agonists decreases feeding, MC4-R deletion induces obesity in rats. $\alpha$-MSH, which is derived from the breakdown of POMC, may be the endogenous ligand for MC4-R. POMC expression in the arcuate nucleus may be increased by leptin, an effect that could be part of a feedback pathway for control of appetite and sympathetic activity. Increasing leptin, associated with obesity, would stimulate arcuate POMC expression and $\alpha-\mathrm{MSH}$, which would then act elsewhere in the hypothalamus on MC4-R-expressing neurons, causing decreased food intake and increased sympathetic activity. Other factors that may influence the MC4-R pathway include agouti-related peptide (AgRP), which acts as an antagonist on this receptor. Yellow agouti mice with ectopic overexpression of agouti peptide are obese and hyperleptinemic owing to antagonism of the hypothalamic melanocortin system by the excess agouti protein. Treating rodents with an MC4-R antagonist completely abolishes the increased renal sympathetic activity associated with short-term ICV leptin infusion in rats. Surprisingly, MC4-R blockade does not prevent leptin-induced stimulation of sympathetic activity in BAT. This suggests that the thermogenic effects of leptin in BAT are not mediated through MC4-R, whereas the short-term effect of leptin to enhance renal sympathetic activity appears to depend on intact MC4-R. These paradoxical effects of MC4-R blockade on BAT and renal sympathetic activity suggest that leptin may activate the SNS through complex central pathways.

The orexins and melanin-concentrating hormone $(\mathrm{MCH})$, which regulate appetite and energy homeostasis, are recently discovered mediators (Sakurai, 1999; Shirasaka et al., 1999). Short-term experiments involving ICV injections of orexins increase renal sympathetic activity, heart rate, and arterial pressure in rats and thereby raise blood pressure. Control mechanisms for orexin release are opposite to those of leptin in that orexin expression usually increases with starvation and decreases with increased energy intake. Therefore, orexin levels are reduced in situations when leptin is increased (e.g., obesity) and thus 
probably do not mediate the hypertensive effects of leptin. However, the importance of orexins and other neurochemical pathways in the hypothalamus in modulating the chronic effects of leptin on sympathetic activity, thermogenesis, and arterial pressure is largely unexplored.

\section{Role of Adipose Tissue and Systemic RAAS}

\section{A. SYSTEMIC RAAS}

The RAAS seems to be activated in obesity, despite a state of volume expansion and sodium retention. Elevated serum aldosterone levels have been reported in the obese (Granger et al., 1994; Schorr et al., 1998; Engeli et al., 2001,2002) and it is postulated that a yet-unidentified factor (possibly a fatty acid) derived from adipose tissue causes the release of a hepatic factor that, in turn, steps up aldosterone synthesis (Goodfriend et al., 1998,1999). Reports in the literature suggest that a relationship between plasma angiotensin (Ang II) levels, plasma renin activity (PRA), and plasma angiotensin-converting enzyme (ACE) with BMI exists in humans (Licata et al., 1994b; Cooper et al., 1997,1998). Sharma and colleagues reported a relationship between plasma leptin and Ang II levels and leptin and PRA. Since plasma leptin levels correlate with adipose tissue mass (Engeli et al., 2000), it is fair to speculate that adipose tissue may directly contribute to circulating Ang II. Sharma and coworkers also noted that a positive family history of hypertension predicts a relationship between plasma Ang II and blood pressure, suggesting a role for genetic factors in Ang II-related blood pressure response (Schorr et al., 1998).

The effect of weight loss on RAAS also has been investigated. On a short-term scale, Tuck and Sowers studied the effect of weight loss on RAAS and blood pressure in 25 obese patients placed on a 12-week weight-reducing diet (Tuck et al., 1981). Sodium intake was either medium or low; PRA, aldosterone, and mean arterial pressure (MAP) were significantly reduced. The reduction in PRA but not in aldosterone correlated with weight loss in both sodium-intake groups. MAP fell significantly and to the same degree in both groups, correlating with weight loss throughout the study and with PRA from weeks 4-12. These results suggest that weight loss is accompanied by reductions in PRA and aldosterone and that PRA reductions may contribute to the decline in blood pressure (Bloem et al., 1995; Umemura et al., 1997; Uckaya et al., 1999; Engeli and Sharma, 2002).

In a nutshell, despite evidence in favor of a stimulated RAAS in obesity, the role of genetic factors continues to be investigated. There is little information on the long-term effect of weight loss on the RAAS; larger studies are needed to investigate the short-term effect. 


\section{B. ADIPOSE TISSUE RAAS}

It is becoming increasingly evident that adipose tissue possesses a local RAAS that plays an important role in adipose tissue function. Recent studies suggest that adipose tissue angiotensinogen mRNA expression is higher in abdominal than subcutaneous adipose tissue and therefore may be associated with increased cardiovascular risk. Fat cells possess the capability to synthesize all components of the RAAS. They apparently also express Ang II receptors, which make them a target for the paracrine-produced Ang II (Giacchetti et al., 1999). That local Ang II may be a growth factor for fat cells is suggested by experiments in angiotensinogen-knockout (KO) mice that exhibit low blood pressure, have hypotrophic fat cells with reduced fatty acid synthase activity, and demonstrate abnormal, diet-induced weight gain (Frederich et al., 1995; Engeli et al., 2000). It has been suggested from studies in these animals that adipose tissue RAAS may govern blood pressure. Massiera and coworkers expressed the angiotensinogen (AGT) gene in adipose tissue of AGT-KO mice, creating a transgenic-KO mouse model in which production of AGT is limited to adipose tissue. In these animals, systemic levels of AGT increased to $20 \%$ of wild-type levels, demonstrating that AGT produced in fat cells can enter the circulation (Massiera et al., 2001). Blood pressure and sodium homeostasis were restored in the transgenic animals, lending further credence to the theory that an increased fat cell mass may result in higher circulating AGT levels, a finding confirmed in obese individuals.

Additional evidence supports the role of adipose tissue in causation of hypertension. A transgenic mouse that overexpresses the cortisol-forming enzyme $11 \beta$-hydroxysteroid dehydrogenase (HSD) 1 develops obesity hypertension and all features of the metabolic syndrome (Masuzaki et al., 2001). This model was found to overexpress angiotensin in adipose tissue and elevated serum angiotensin levels. Obese hypertensive women have been found to overexpress genes encoding renin, angiotensin-converting enzyme (ACE), and Ang II type 1 receptor in subcutaneous abdominal fat cells (Gorzelniak et al., 2002). Despite the fact that expression of the AGT gene is lower in the obese, the high Ang II levels in circulation may be derived from the huge fat cell mass, resulting in hypertension. It recently has been reported that mutations in the DD phenotype of the ACE gene may be associated with obesity hypertension in Caucasian men.

\section{Role of the Natriuretic Peptide System}

The natriuretic peptide system consists of the atrial natriuretic peptide (ANP), the brain natriuretic peptide (BNP), and the C-type natriuretic peptide (CNP), each encoded by a separate gene (Rosenzweig and Seidnan, 1991; Maack, 1992; Maoz et al., 1992; Nakao et al., 1992; Sarzani et al., 1993,1996; 
Dessi-Fulgheri et al., 1998). They are synthesized predominantly in the heart, brain, and kidneys. They work via specific receptors, namely, NPr-A, NPr-B, and NPr-C (Nakao et al., 1992; Levin et al., 1998). The natriuretic peptides have salutary effects on plasma volume, renal sodium handling, and blood pressure and cause a reduction in sympathetic tone in the peripheral vasculature. They dampen baroreceptor function and lower the activation threshold of vagal efferents, suppressing reflex tachycardia and vasoconstriction resulting from decreased extracellular volume. Transgenic mice that overexpress the ANP gene have lower blood pressure, while animals with inactivated ANP gene are prone to develop salt-sensitive hypertension (Melo et al., 1998,2000). Therefore, the natriuretic peptides have a protective role on the development of hypertension due to their natriuretic and vasodilator effects as well as due to their inhibitory effect on the SNS and the RAAS.

It has been noted that the NPr-C receptor is overexpressed in adipose tissue in the obese. This may adversely affect the systemic activity and actions of the natriuretic peptides, leading to sodium retention and hypertension. It has been reported that ANP plasma levels are lower in the obese hypertensive than in obese normotensive subjects (Dessi-Fulgheri et al., 1997). These obese hypertensive subjects also demonstrate a stronger response to exogenously administered ANP, as measured by blood pressure reduction, natriuresis, and increases in urine cyclic guanylate monophosphate (cGMP) excretion (Dessi-Fulgheri et al., 1999). These effects are pronounced after these subjects have been on a low-calorie diet for a span of time, rather than at baseline. The ANP response to salt load was found to be suppressed in the obese, compared to a potent ANP elevation in the lean. Concomitantly, PRA and aldosterone were suppressed in the obese when saline challenged. Obese rats that were subjected to $40 \%$ weight loss by caloric restriction demonstrated a significant increase in circulating ANP levels as well as a strong decrease in PRA (Crandall et al., 1989). A recent study reported an association between a promoter variant at position -55 in the $\mathrm{NPr}-\mathrm{C}$ gene, a higher blood pressure, and lower ANP plasma levels in obese hypertensive subjects (Sarzani et al., 1999). Further studies are needed to understand the role of this finding re: its possible contribution to blood pressure elevation.

\section{Cardiovascular System Changes}

\section{A. VASCULAR ADAPTATIONS}

An alteration in ions at the cellular and molecular level appears to be important in regulating vascular smooth muscle tone. These may be deregulated in the obese, resulting in abnormal vascular responsiveness (Messerli et al., 1981; Frohlich et al., 1983; Assmann and Schulte, 1998). Insulin works as a vasodilator by inhibiting voltage-gated $\mathrm{Ca}^{2+}$ influx. It also stimulates glucose transport and 
phosphorylation of glucose to glucose-6-phosphate, which further activates $\mathrm{Ca}^{2+}$ ATPase transcription and increases cellular $\mathrm{Ca}^{2+}$ efflux. These actions result in a net decrease in intracellular $\mathrm{Ca}^{2+}$ and, therefore, decreased vascular resistance. These effects are blunted in obesity due to insulin resistance, leading to increased vascular resistance (Terazi, 1983; Licata et al., 1990; Rocchini et al., 1992; Rochstroph et al., 1992; Schmieder and Messerli, 1993; Weir et al., 1998; Zemel, 1998).

Resnick and colleagues (1997) discovered that increased abdominal visceral fat, decreased intracellular magnesium, and advanced age were closely associated with reduced aortic distensibility. In this study, magnetic resonance imaging (MRI) was utilized to evaluate the aorta of normal and hypertensive subjects.

Jacobs and Sowers studied the effect of weight reduction on peripheral vascular resistance (PVR), reflected by forearm vascular resistance and MAP in obese persons. Weight loss resulted in a clearly significant decrease in PVR and MAP (Jacobs et al., 1993).

\section{B. CARDIAC ADAPTATIONS}

Obesity is a major cause of type I diabetes, hypertension, and hyperlipidemia. These disorders individually and synergistically increase the cardiovascular risk, as shown in the Prospective Cardiovascular Munster (PROCAM) study (Assmann and Schulte, 1988).

Prolonged hypertension in lean subjects tends to produce a concentric left ventricular hypertrophy $(\mathrm{LVH})$, whereas the predominant pattern of cardiac hypertrophy noted in obese hypertensives is eccentric. With concentric hypertrophy, cardiac dilatation is a late and terminal event (Frohlich et al., 1992; Simon et al., 1994). Heart failure is more common in the obese subject, even when corrected for the presence of hypertension (Drenick et al., 1980). The presence of both obesity and hypertension in a patient results in a mixed pattern of cardiac hypertrophy, caused by an elevation in both cardiac preload and afterload (Messerli et al., 1983). Obesity results in increased preload due to an expanded vascular volume, while the high afterload can be accounted for by the presence of hypertension and SNS activation. After adjustment for established risk factors, the risk of heart failure increases by $5 \%$ in men and $7 \%$ in women for each BMI increment of 1 (Kenchaiah et al., 2002). Compared with subjects having a BMI below the obese range, obese subjects have double the risk of heart failure, after adjustment for co-morbid risk factors. Autopsy data from the Mayo Clinic reveal that the average cardiac mass is $467 \mathrm{~g}$ in obese hypertensive subjects, compared with $367 \mathrm{~g}$ in obese individuals without heart disease and $272 \mathrm{~g}$ in nonobese hypertensive subjects (Smith and Willius, 1933). Since LVH itself is a major risk factor for sudden death and death due to progressive cardiac decompensation, it may partially explain the increased incidence of cardiovas- 
cular morbidity and mortality in the obese (Lip et al., 1994). Mononuclear cell infiltration in and around the sinoatrial node, with fat deposition all along the conduction system, is present in the myocardium of obese individuals (Bharati and Lev, 1995). Lipomatous hypertrophy of the interatrial septum also has been noted in obesity (Basa et al., 1994). All these changes make the myocardium in the obese hypertensive an ideal substrate for cardiac arrhythmia and sudden death (Duflou et al., 1995).

\section{Proinflammatory and Prothrombotic Changes}

\section{A. ADIPOSE TISSUE IS A SOURCE OF INFLAMMATORY CYTOKINES AND HORMONES}

Adipose tissue in general and central adipose tissue in particular is recognized as a rich milieu and source of inflammatory cytokines, such as tumor necrosis factor- $\alpha$ (TNF- $\alpha$ ), interleukin-6 (IL-6), and C-reactive protein (CRP), and plasminogen activator inhibitor (PAI-1). As such, obesity has been suggested to be a low-grade inflammatory condition increasingly important in the causation and progression of hypertension and atherosclerosis (Festa et al., 2000; Das, 2001). It is thought that the central adipocyte synthesizes TNF- $\alpha$, which, in turn, stimulates IL-6, considered a major regulator in the production of acute-phase reactants such as CRP, PAI-1, and fibrinogen from the hepatocyte.

It is possible that the relationship between obesity and vascular disease may depend in part on the increased production and release of these inflammatory mediators from adipose tissue. A direct cause-and-effect relationship, however, has not been clearly established. It is not known, for example, whether long-term treatment with aspirin or other nonsteroidal anti-inflammatory drugs reduces the level of inflammatory cytokines and CVD in obese patients.

\section{B. HYPERCOAGULATION AND INCREASED RISK OF THROMBOSIS IN OBESITY}

Increased risk for thrombosis may contribute to a higher incidence of heart disease and stroke in obesity. Obesity is associated with polycythemia. Epidemiologic evidence exists that hypercoagulation and impaired fibrinolysis activity are related to BMI or waist-to-hip ratio. For example, obese subjects have higher levels of factor VII antigen, fibrinogen, plasminogen, and PAI-1 activity, all of which have been suggested to increase the risk for CVD (Alessai et al., 2000; Chu et al., 2001; Rissanen et al., 2001). The increased flux of FFAs in obesity may promote thrombosis by increasing protein C, PAI-1, and/or platelet aggregation. Adipose tissue production of leptin or inflammatory mediators have been suggested as important factors causing increased thrombosis (Konstantinides et 
al., 2001) but these aspects of the relationship between obesity and CVD are poorly understood and require additional study. Other mechanisms for platelet activation in the obese recently have been elucidated, at least in part. Davi and coworkers (2002) reported that a visceral or android pattern of obesity is associated with lipid peroxidation and persistent platelet activation, both of which appear partially reversible with weight loss. An association has been proposed between a circulating soluble CD40 ligand (CD40L) and platelet activation. CD40L is a trimeric, transmembrane protein of the TNF family that is inactive in resting platelets but is rapidly activated and expressed on the platelet surface when the platelet is stimulated. Therefore, increased levels of circulating CD40L represent an index of platelet activation. Desideri and Ferri (2003) addressed the relationship between central obesity and circulating levels of soluble CD40L and the effect of weight loss on this measure of platelet activation in a prospective intervention cohort study. It was found that baseline levels of circulating CD40L and 8-iso-PGF2 $\alpha$ levels (a marker of lipid peroxidation) were significantly higher in obese vs. nonobese subjects. BMI levels correlated well with levels of CD40L and 8-iso-PGF2 $\alpha$. After a 16-week intervention period of caloric restriction and weight loss, levels of these markers went down, corresponding with a commensurate lowering of the BMI in the obese subjects.

\section{Management}

\section{A. PHYSICAL EXERCISE}

Increased physical activity is perhaps the most-widely prescribed and the most-poorly complied with of all weight-reduction strategies. It requires considerable time, thought, and effort from the patient and the therapist. Physical activity is essential for long-term weight control. It appears to be the best predictor of maintenance of weight loss. Even in the absence of weight loss, increased physical activity is associated with other desirable outcomes, such as improved cardiovascular health and perhaps reduction in insulin resistance. Studies suggest that, in overweight and obese persons, physical activity is independently associated with the redistribution of adiposity away from the abdomen. It is important not to set inappropriately ambitious physical activity goals, since they increase the likelihood that the exercise program will be abandoned. High levels of aerobic physical activity at a fitness center are not needed to obtain health benefits. Several studies have compared the impact of lifestyle activity vs. physical exercise and demonstrated that they result in similar health benefits (e.g., control of hypertension and body fat) (Andersen et al., 1999). Based on these and other observations, it is clearly inappropriate to suggest to patients that the only acceptable physical activity included in their 
weight-loss program would be vigorous in nature. Although some may choose this, those who don't should be encouraged to start with low-impact, moderateintensity physical activity (i.e., walking) of short duration, with a goal of accumulating at least 30 minutes of physical activity on most days of the week. A recent report suggests that physical activity participation for 60 minutes per day will impart increased benefits and is more likely to help maintain weight loss.

\section{B. CALORIC RESTRICTION}

Caloric restriction seems the most-important component of obesity management. A daily caloric reduction of 500-1000 cal produces a weight loss of $0.45-0.90 \mathrm{~kg} /$ week. Individually planned diets that incorporate all essential dietary components should be made available to everyone entering a weight-loss program. Many types of diets — including high-protein, low-carbohydrate, and low-fat - have been promoted. The individual macronutrient component of diet is controversial and has not been determined (Jackic et al., 2001). All low-calorie diets produce weight loss and macronutrient composition seems less important than the number of calories cut (Freedman et al., 2001).

\section{BEHAVIORAL MODIFICATION}

Behavioral therapy is a very important component of any weight-loss program. It helps patients develop the skills they need to identify and modify eating and activity behaviors. It also helps remodel thinking patterns that undermine weight-control measures (Wadden et al., 2000). Important components of behavioral therapy are self weight monitoring, measuring intake by keeping a food log, and physical activity. Other strategies are identification of stimuli that trigger unusual, irregular food intake or binging on food and problem solving, which identifies problems and proposes solutions. Behavioral strategies encompass the active and supportive involvement of the social and family fabric that surrounds the patient. Stress and time management are also essential to a comprehensive weight-loss program. Patients who appear depressed and have poor self-image should receive appropriate referral to psychotherapists, support groups in the community, and, if deemed necessary, a psychiatrist. Professional help from dieticians, nurse educators, and exercise physiologists should be readily available (Boutelle and Kirschenbaum, 1998).

\section{PHARMACOTHERAPY}

Because antihypertensive drug treatment in obesity hypertension is not yet based on evidence from large, randomized, controlled trials that have specifically addressed this population, it remains empirical. No definitive guidelines have been framed; therefore, only suggestions can be made based upon assumed 
pathophysiologic mechanisms and clinical experience. For example, since $\beta$-blockers can result in weight gain and impair glucose tolerance, their use in uncomplicated obesity and hypertension cannot be recommended as routine first-line therapy (Sharma et al., 2001). This recommendation cannot extend across the board to patients admitted to critical care units with acute coronary syndromes where $\beta$-blockers are not only essential but also may be lifesaving. They may be used to manage patients with hypertension uncontrolled with multiple other agents. The importance of adrenergic blockade in the management of this syndrome cannot be dismissed (Wofford et al., 2001). It was shown by Masuo et al. $(2001 \mathrm{a}, \mathrm{b})$ that subjects who were resistant to weight loss-induced blood pressure reductions possessed a highly active SNS and would potentially benefit from adrenergic blockade. Calcium channel blockade cannot be recommended in obese hypertensive patients, since some small studies have cast doubt on their efficacy. No definitive recommendations can be made until data from large, randomized, controlled trials are gathered (Schmieder et al., 1993; Masuo et al., 2001a,b).

ACE inhibitors and angiotensin-receptor blockers (ARBs) may be considered preferred agents for several reasons. First, they are metabolically neutral, except for the risk of hyperkalemia, which can be managed effectively with careful monitoring. Second, there is evidence from the Heart Outcomes Prevention Evaluation (HOPE) and Captopril Prevention Project (CAPPP) trials (Hansson et al., 1999; Yusuf et al., 2000) that ACE inhibitors may prevent or retard the development of type 2 diabetes. Third, this class of agents may be the most effective in preventing the onset and progression of proteinuria that are responsible for the inexorable progression to obesity-hypertension-related ESRD. Finally, this class of agents may be the most effective to prevent and manage eccentric cardiac hypertrophy and thus progression to heart failure. Low-dose ACE inhibitors may be more effective than thiazides (Reisin et al., 1997; Yusuf et al., 2000; Wofford et al., 2001). Therefore, it may be reasonable to recommend ACE inhibitors and ARBs as first-line therapy for obesity-related hypertension. Thiazide diuretics may be an effective class of agents for this group of patients, since they directly address the volume-expanded state of the obesity-hypertension syndrome (Reisen et al., 1997) and may prevent cardiac dilatation by preload reduction. Caution must be exercised with use in this class of patients, primarily for the risk of exacerbating dysglycemia and erectile dysfunction, which are quite prevalent in this population. Excessive diuresis may result in a state of volume contraction, triggering further activation of the SNS and the RAAS, resulting in avid renal salt and fluid retention, with exacerbation of hypertension. Indeed, a combination of ACE inhibitors and low-dose thiazides may be more effective than either strategy alone in this population. Having said that, it is important to note that there is little evidence to support these hypotheses. 
Weight loss - achieved by exercise, behavioral modification, pharmaceutical agents, or a combination - is another important and effective means of reversing insulin resistance, elevated leptin levels, decreased cardiac output, and activated SNS (Emdin et al., 2001; Itoh et al., 2001; Nakano et al., 2001). Despite significant initial success, long-term and sustained weight loss is difficult to achieve with diet and exercise alone.

Some recently developed pharmaceutical agents (e.g., orlistat, sibutramine) have shown good promise in achieving significant and sustained weight loss in the range of $5-10 \%$. In a recent meta-analysis that pooled data from trials using orlistat (30\% of participating subjects were hypertensive), significant blood pressure reductions were noted after 1 year in subjects who lost $5 \%$ or more weight. The blood pressure reductions were on the order of $7 \mathrm{mmHg}$ systolic and $5.5 \mathrm{mmHg}$ diastolic, comparable to those achieved with antihypertensives used as single agents (Zavoral, 1998). Other cardiovascular risk factors improved significantly in subjects who took orlistat for more than 2 years (Rossner et al., 2000). Since orlistat has no negative effect on the cardiovascular risk profile, it can be safely recommended for treating the obese patient with hypertension.

Sibutramine, another anti-obesity medication, acts by inhibiting serotonin and norepinephrine uptake. In doing so, it enhances satiety and increases energy utilization (Hansen et al., 1999). A recent trial called STORM (Sibutramine in Obesity Reduction and Management) revealed significant and sustained weight loss comparable to that achieved with orlistat. Improvement in metabolic parameters such as blood glucose and lipid levels was also noted (Hansen et al., 2001). However, small increases in blood pressure and heart rate were noted and no net blood pressure reductions could be achieved commensurate with the degree of weight loss. In another trial with sibutramine, those who maintained weight at 1 year had no significant changes in blood pressure and heart rate, when compared to baseline (McMahon et al., 2000). Therefore, sibutramine cannot be recommended in the hypertensive-obese subject. If it must be used, careful blood pressure monitoring is warranted with use of effective antihypertensive medications.

Novel weight-loss medications have been reported recently. A randomized control trial conducted with zonisamide (an anti-epileptic agent with dosedependent biphasic dopaminergic and serotonergic activity) resulted in significantly greater weight loss and reductions in blood pressure, compared to lifestyle intervention alone in the extended phase of the trial. The drug was found to be safe, with fair compliance (Gadde et al., 2003). Therapy with a recombinant variant of ciliary neurotrophic factor (rhvCNTF) resulted in significant weight loss. This agent that was developed for the management of amyotrophic lateral sclerosis (a type of motor neuron disease) did not prevent disease progression but resulted in weight loss. It is thought to exert its effect by binding to the CNTF receptor and activating leptin-like intracellular signaling pathways (janus kinases 
and signal transducers and activators of transcription 3) in hypothalamic nuclei, thereby regulating food intake and body weight (Ettinger et al., 2003). Despite significant weight loss, no significant effect on blood pressure was noted. The drug must be administered subcutaneously. Other agents such as SR141716 (Rimonabant) are in phase 3 trials. Rimonabant acts by blocking a cannabinoid receptor in the CNS that, when activated, stimulates hunger.

\section{E. ROLE OF BARIATRIC SURGERY}

The National Institutes of Health criteria for obesity surgery eligibility are a well-informed and motivated patient with a BMI $>40$ or a patient with less-severe obesity (i.e., BMI > 35) with high-risk, co-morbid conditions (e.g., type 2 diabetes, cardiopulmonary problems). Trials such as the Swedish Obesity Study (SOS) found that weight-reduction surgery in the morbidly obese with significant co-morbidities can result in improved metabolic parameters and blood pressure. Surgery is an option for patients in whom all conservative measures, including pharmaceutical agents, have failed and in those who cannot tolerate drugs due to their prohibitive side effects. These procedures entail considerable operative risk and pose ethical and scientific questions, so cannot yet be routinely recommended (Sjostrom et al., 2001; Torgerson and Sjostrom, 2001; Laimer et al., 2002; Nabro et al., 2002).

\section{Summary}

This review has discussed some of the mechanisms involved in the causal relation between obesity and hypertension. Obesity causes a constellation of maladaptive disorders that individually and synergistically contribute to hypertension among other cardiovascular morbidity. Well-designed, population-based studies are needed to assess the individual contribution of each of these disorders to the development of hypertension. Control of obesity may eliminate $48 \%$ of the hypertension in whites and $28 \%$ in blacks. We hope that this chapter will help scientists formulate a thorough understanding of obesity hypertension and form the basis for more research in this field, which greatly impacts on human life.

\section{REFERENCES}

Abate NI, Mansour YH, Arbique D, et al. 2001 Overweight and sympathetic activity in black Americans. Hypertension 38:379-383

Aizawa-Abe M, Ogawa Y, Mazuzaki H, Ebihara K, Saton N, Iwai H, Matsuoka N, Hayashi T, Hosoda K, Inoue G, Yoshimasa Y, Nakao K 2000 Pathophysiological role of leptin in obesity related hypertension. J Clin Invest 105:1243-1252

Alessai MC, Morange P, Juhan-Vague I 2000 Fat cell function and fibrinolysis. Horm Metab Res 32:504-508 
Alexander J, Dustan HP, Sims EAH, Tarazi R 1979 Report of the Hypertension Task Force. Washington, DC: US Government Printing Office, US Department of Health, Education, and Welfare, publication 70-1631; 61-77

Alonso-Galicia M, Dwyer TM, Herrera GA, Hall JE 1995 Increased hyaluronic acid in the inner medulla of obese dogs. Hypertension 25:888-892

Andersen RE, Wadden TA, Bartlett SJ, Zemel B, Verde TJ, Franckowiak SC 1999 Effects of lifestyle activity vs structured aerobic exercise in obese women: a randomized trial. JAMA 281:335-340

Antic V, Kiener-Belforti F, Tempini A, Van Vliet BN, Montani J-P 2000 Role of the sympathetic nervous system during the development of obesity hypertension in rabbits. Am J Hypertens 13:556-559

Arnold MD, Brissie R, Soonz JS, et al. 1994 Obesity associated renal medullary changes. Lab Invest 70:156A (abstract)

Assmann G, Schulte H 1988 The Prospective Cardiovascular Munster Study (PROCAM): prevalence of hyperlipidemia in persons with hypertension and/or diabetes mellitus and the relationship to coronary artery disease. Am Heart J 1116:1713-1724

Baron AD, Steinberg HO, Chaker H 1995 Insulin mediated skeletal muscle vasodilation contributed to both insulin sensitivity and responsiveness in lean humans. J Clin Invest 96:786-792

Basa S, Folliguet T, Anselmo M, Greengart A, Sabado M, Cunningham JN, Jacobowitz IJ 1994 Lipomatous hypertrophy of the interatrial septum. Cardiovasc Surg 2:229

Bergman RN, Van Citters GW, Mittelman SD, et al. 2001 Central role of adipocyte in the metabolic syndrome. J Invest Med 49:119-126

Bharati S, Lev M 1995 Cardiac conduction system involvement in sudden death of obese young people. Am Heart J 129:273-281

Bjorntorp P, Rosmond R 2000 Neuroendocrine abnormalities in visceral obesity. Intl J Obes Relat Metab Disord 24:S80-S85

Bloem LJ, Manatunga AK, Tewksbury DA, Pratt JH 1995 The serum angiotensinogen concentration and variants of the angiotensinogen gene in white and black children. J Clin Invest 95:948-953

Bloomfield GL, Sugerman HJ, Blocher CR, et al. 2000 Chronically increased intra-abdominal pressure produced systemic hypertension in dogs. Intl J Obes Relat Metab Disord 24:819824

Boston BA, Blaydon KM, Varnerin J, Cone RD 1997 Independent and additive effects of central POMC and leptin pathways on murine obesity. Science 278:1641-1644

Boutelle KN, Kirschenbaum DS 1998 Further support for consistent self-monitoring as a vital component of successful weight control. Obes Res 6(3):219-224

Brands MW, Harrison DL, Keen HL, Gardner A, Shek EW, Hall JE 1997 Insulin-induced hypertension in rats is dependent on an intact renin-angiotensin system. Hypertension 29:1014-1019

Bruzzi I, Benigni A, Remuzzi G 1997 Role of increased glomerular protein traffic in the progression of renal failure. Kidney Intl 62:529-532

Burt V, et al. 1995 NHANES II and III. Hypertension 26:60-69

Cardillo C, Kilcoyne CM, Cannon RO III, Panza JA 2000 Increased activity of endogenous endothelin in patients with hypercholesterolemia. J Am Coll Cardiol 36(5):1483-1488

Carlyle M, Jones OB, Kuo JJ, et al. 2002 Chronic cardiovascular and renal actions of leptin — role of adrenergic activity. Hypertension 39:496-501

Carrol JF, Huang M, Hester RL, Cockrell K, Mizelle HL 1995 Hemodynamic alterations in obese rabbits. Hypertension 26:465-470

Casto RM, VanNess JM, Overton JM 1998 Effects of central leptin administration on blood pressure in normotensive rats. Neurosci Lett 246:29-32 
Chu NF, Spiegelman D, Hotamisligil GS, et al. 2001 Plasma insulin, leptin, and soluble TNF receptors levels in relation to obesity-related atherogenic and thrombogenic cardiovascular disease factors among men. Atherosclerosis 157:495-503

Cignolini M, Seidell JC, Targher JP, et al. 1995 Fasting serum insulin in relation to components of the metabolic syndrome in European healthy men: the European fat distribution study. Metabolism 44:35-40

Considine RV 2001 Regulation of leptin production. Rev Endocr Metab Disord 2:357-363

Considine RV, Sinha MK, Heiman ML, Kriauciunas A, Stephens TW 1996 Serum immunoreactive leptin concentrations in normal-weight and obese humans. N Engl J Med 334:292-295

Cooper R, McFarlane Anderson N, Bennett FI, Wilks R, Puras A, Tewksbury D, Ward R, Forrester T 1997 ACE, angiotensinogen and obesity: a potential pathway leading to hypertension. J Hum Hypertens 11:107-111

Cooper R, Forrester T, Ogunbiyi O, Muffinda J, on behalf of the ICSHIB Investigators 1998 Angiotensinogen levels and obesity in four black populations. J Hypertens 16(5):571-575

Crandall DL, Ferraro GD, Cervoni P 1989 Effect of experimental obesity and subsequent weight reduction upon circulating atrial natriuretic peptide. Proc Soc Exp Biol Med 191:352-356

Das UN 2001 Is obesity an inflammatory condition? Nutrition 17:953-966

Davi G, Guagnano MT, Ciabattoni G, et al. 2002 Platelet activation in obese women: role of inflammation and oxidative stress. JAMA 288:2008-2014

DeFronzo RA, Cooke CR, Andres R, Fabona GR, Davis PJ 1975 The effect of insulin on renal handling of sodium, potassium, calcium and phosphate in man. $\mathbf{J}$ Clin Invest 55:845-855

Desideri G, Ferri C 2003 Effects of obesity and weight loss on soluble CD 40L levels. JAMA 289:1781-1782

Dessi-Fulgheri P, Sarzani R, Tamburrini P, Moraca A, Espinosa E, Cola G, Giantomassi L, Rappelli A 1997 Plasma atrial natriuretic peptide and natriuretic peptide receptor gene expression in adipose tissue of normotensive and hypertensive obese patients. J Hypertens 15:1695-1699

Dessi-Fulgheri P, Sarzani R, Rappelli A 1998 The natriuretic peptide system in obesity-related hypertension: new pathophysiology aspects. J Nephrol 11:296-299

Dessi-Fulgheri P, Sarzani R, Serenelli M, Tamburrini P, Spagnolo D, Giantomassi L, Espinosa E, Rappelli A 1999 Low calorie diet enhances renal, hemodynamic, and humoral effects of exogenous atrial natriuretic peptide in obese hypertensives. Hypertension 33:658-662

Dobrian AD. Davies MJ, Prewitt RL, et al. 2000 Development of a rat model of diet-induced obesity. Hypertension 35:1009-1015

Drenick EJ, Bale GS, Seltzer F, Johnson DG 1980 Excessive mortality and cause of death in morbidly obese men. JAMA 243:443-445

Duflou J, Virmani R, Rabin J, Burke A, Farb A, Smialek J 1995 Sudden death as a result of heart disease in morbid obesity. Am Heart J 130:306-313

Dunn AL, Marcus BH, Kampert JB, Garcia ME, Kohl HW III, Blair SN 1999 Comparison of lifestyle and structured interventions to increase physical activity and cardiorespiratory fitness: a randomized trial. JAMA 281:327-334

El-Haschimi K, Pierroz DD, Hileman SM, Bjorbaek C, Flier JS 2000 Two defects contribute to hypothalmic leptin resistance in mice with diet-induced obesity. J Clin Invest 105:1827-1832

Emdin M, Gastaldelli A, Muscelli E, et al. 2001 Hyperinsulinemia and autonomic nervous system dysfunction in obesity: effects of weight loss. Circulation 103:513-519

Engeli S, Sharma AM 2001 The renin-angiotensin system and natriuretic peptides in obesityassociated hypertension. J Mol Med 79:21-29

Engeli S, Sharma AM 2002 Emerging concepts in the pathophysiology and treatment of obesityassociated hypertension. Curr Opin Cardiol 17:355-359 
Engeli S, Negrel R, Sharma AM 2000 Physiology and pathophysiology of the adipose tissue renin-angiotensin system. Hypertension 35:1270-1277

Esler M 2000 The sympathetic system and hypertension. Am J Hypertens 13:99S-105S

Ettinger MP, Littlejohn TW, Schwartz SL, Weiss SR, McIlwain HH, Heymsfield SB, Bray GA, Roberts WG, Heyman ER, Stambler N, Heshka S, Vicary C, Guler H 2003 Recombinant variant of ciliary neurotrophic factor for weight loss in obese adults: a randomized, doseranging study. JAMA 289:1826-1832

Fan W, Boston BA, Kesterson RA, Hruby VJ, Cone RD 1997 Role of melanocortinergic neurons in feeding and the agouti obesity syndrome. Nature 385:165-168

Festa A, D'Agostino R Jr, Howard G, et al. 2000 Chronic subclinical inflammation as part of the insulin resistance syndrome: the Insulin Resistance Atherosclerosis Study (IRAS). Circulation 102:42-47

Flegal KM, Carroll MD, Kuczmarski RJ, et al. 1998 Overweight and obesity in the United States: prevalence and trends, 1960-1994. Intl J Obes Relat Metab Disord 22:39-47

Flier JS 1998 Clinical review 94: What's in a name? In search of leptin's physiologic role. J Clin Endocrinol Metab 83:1407-1413

Flier JS, Maratos-Flier E 1998 Obesity and the hypothalamus: novel peptides for new pathways. Cell 92:437-440

Frederich RC, Hamann A, Anderson S, Lollmann B, Lowell BB, Flier JS, Hamilton BS, Paglia D, Kwan AY, Deitel M, Lonnqvist F, Arner P, Nordfors L, Schalling M 1995 Leptin levels reflect body lipid content in mice: evidence for diet-induced resistance to leptin action. Nature Med 1:950-953

Freedman MR, King J, Kennedy E 2001 Popular diets: a scientific review. Obes Res 9(suppl 1):S1-S40

Frohlich ED, Epstein C, Chobanian AV, Devereux RB, Dustan HP, Dzau V, Fauad-Tarazi F, Horan MJ, Marcus M, Massie B 1992 The heart in hypertension. N Engl J Med 327:998-1008

Frohlich ED, Messerli FH, Reisin E, Dunn FG 1983 The problem of obesity and hypertension. Hypertension 5:S71-S78

Frubeck G 1999 Pivotal role of nitric oxide in the control of blood pressure after leptin administration. Diabetes 48:903-908

Gadde KM, Franciscy DM, Wagner HR II, Krishnan KRR 2003 Zonisamide for weight loss in obese adults. JAMA 289:1820-1825

Garrison RJ, Kannel WB, Stokes J, Castelli WP 1987 Incidence and precursors of hypertension in young adults: the Framingham Offspring Study. Prev Med 16:234-251

Giacchetti G, Faloia E, Sardu C, Mariniello B, Garrapa GGM, Gatti C, Camilloni MA, Mantero F 1999 Different gene expression of the RAS in human adipose tissue. Intl J Obes Relat Metab Disord 23:S71

Golden P, MacCagnan TJ, Pardridge WM 1997 Human blood-brain barrier leptin receptor: binding and endocytosis in isolated human brain microvessels. J Clin Invest 99:14-18

Goodfriend TL, Egan BM, Kelley DE 1998 Aldosterone in obesity. Endocr Res 24:789-796

Goodfriend TL, Egan BM, Kelley DE 1999 Plasma aldosterone, plasma lipoproteins, obesity and insulin resistance in humans. Prostagland Leukot Essent Fatty Acids 60:401-405

Gorzelniak K, Engeli S, Janke J, et al. 2002 Hormonal regulation of the human adipose-tissue renin-angiotensin system: relationship to obesity and hypertension. J Hypertens 20:11151120

Granger JP, West D, Scott J 1994 Abnormal pressure natriuresis in the dog model of obesityinduced hypertension. Hypertension 23:I8-I11 
Grassi G, Servalle G, Cattaneo BM, Bolla GB, Lanfranchi A, Colombo M, Giannattasio C, Brunani A, Cavagnini F, Mancia G 1995 Sympathetic activity in obese normotensive subjects. Hypertension 25:560-563

Grassi G, Seravalle G, Columbo M, Bolla G, Cattaneo BM, Cavagnini F, Mancia G 1998 Body weight reduction sympathetic nerve traffic and arterial baroreflex in obese normotensive humans. Circulation 97:2037-2042

Grekin RJ, Dumont CJ, Vollmer AP, Watts SW, Webb RC 1997 Mechanisms in the pressor effects of hepatic portal venous fatty acid infusion. Am J Physiol 273:R324-R330

Gupta AK, Clark RV, Kirchner KA 1992 Effects of insulin on renal sodium excretion. Hypertension 19(suppl 1):I78-I82

Hall JE 1993 Hyperinsulinemia: a link between obesity and hypertension? Kidney Intl 43:1402-1417

Hall JE 1994 Renal and cardiovascular mechanisms of hypertension in obesity. Hypertension 23:381-394

Hall JE 1997 Mechanisms of abnormal renal sodium handling in obesity hypertension. Am J Hypertens 10:49S-55S

Hall JE, Granger JP, Hester RL, Montani J-P 1986 Mechanisms of sodium balance in hypertension: role of pressure natriuresis. J Hypertens 4:S57-S65

Hall JE, Van Vliet BN, Garrity CA, Torrey C, Brands MW 1993a Obesity hypertension: role of adrenergic mechanisms. Hypertension 21:528

Hall JE, Brands MW, Dixon WN, Smith MJ Jr 1993b Obesity-induced hypertension: renal function and systemic hemodynamics. Hypertension 22:292-299

Hall JE, Brands MW, Zappe DH, Dixon WN, Mizelle HL, Reinhart GA, Hildebrandt DA 1995 Hemodynamic and renal responses to chronic hyperinsulinemia in obese, insulin resistant dogs. Hypertension 25:994-1002

Hall JE, Zappe DH, Alonso-Galicia M, Granger JP, Brands MW, Kassab SE 1996 Mechanisms of obesity-induced hypertension. News Physiol Sci 11:255-261

Hall JE, Brands MW, Henegar JR, Shek EW 1998 Abnormal kidney function as a cause and a consequence of obesity hypertension. Clin Exp Pharmacol Physiol 25:58-64

Hall JE, Brands MW, Henegar JR 1999a Mechanisms of hypertension and kidney disease in obesity. Ann NY Acad Sci 892:91-107

Hall JE, Shek EW, Brands MW 1999b Is leptin a link between obesity and hypertension? Curr Opin Endocrinol Diab 6:225-229

Hall JE, Hildebrandt DA, Kuo J 2001 Obesity hypertension: role of leptin and sympathetic nervous system. Am J Hypertens 14:103S-115S

Hall JE, Crook ED, Jones DW, Wofford MR, Dubbert PM 2002 Mechanisms of obesityassociated cardiovascular and renal disease. Am J Med Sci 324:127-137

Hansen DL, Toubro S, Stock MJ, et al. 1999 The effect of sibutramine on energy expenditure and appetite during chronic treatment without dietary restriction. Intl J Obes 23:1016-1024

Hansen D, Astrup A, Toubro S, et al. 2001 Predictors of weight loss and maintenance during 2 years of treatment by sibutramine in obesity: results from the European multi-centre STORM trial. Intl J Obes 25:496-501

Hansson L, Lindholm LH, Niskanen L, et al. 1999 Effect of angiotensin-converting enzyme inhibition compared with conventional therapy on cardiovascular morbidity and mortality in hypertension: the Captopril Prevention Project (CAPPP) randomised trial. Lancet 353:611616

Haynes WG, Sivitz WI, Morgan DA, Walsh SA, Mark AL 1997 Sympathetic and cardiorenal actions of leptin. Hypertension 30:619-623

Haynes WG, Morgan DA, Djalali A, Mark AL 1998a Activation of melanocortin-4 receptors enhances thermogenic sympathetic nerve activity to brown adipose tissue. Hypertension $32: 620$ 
Haynes WG, Morgan DA, Walsh SA, Sivitz WI, Mark AL 1998b Cardiovascular consequences of obesity: role of leptin. Clin Exp Pharmacol Physiol 25:65-69

Haynes WG, Morgan DA, Djalali A, Sivitz WI, Mark AL 1999 Interactions between the melanocortin system and leptin in control of sympathetic nerve traffic. Hypertension 33:542547

He Q, Ding ZY, Fong DY, Karlberg J 2000 Blood pressure is associated with body mass index in both obese and normal children. Hypertension 36:165-170

Henegar JR, Bigler SA, Henegar LK, et al. 2001 Functional and structural changes in the kidney in the early stages of obesity. J Am Soc Nephrol 12:1211-1217

Hildebrandt DA, Mizelle HL, Brands MW, Hall JE 1993 Systemic hemodynamic actions of long-term intravertebral angiotensin II infusion. FASEB J 7:A405

Hildebrandt DA, Kirk D, Hall JE 1999a Renal and cardiovascular responses to chronic increases in cerebrovascular free fatty acids. FASEB 13:A780

Hildebrandt DA, Smith MJ Jr, Hall JE 1999b Cardiovascular regulation during acute and chronic vertebral artery insulin infusion in concious dogs. J Hypertens 17:252-260

Hirose H, Saito I, Tsujioka M, Mori M, Kawabe H, Saruta T 1998 The obese gene product, leptin: possible role in obesity-related hypertension in adolescents. J Hypertens 16:2007-2012

Huang Z, Willett WC, Manson JE, et al. 1998 Body weight. Weight change and the risk of hypertension in women. Ann Intern Med 128:81-88

Huszar D, Lynch CA, Fairchild-Huntress V, Dunmore JH, Fang Q, Berkemeier LR, Gu W, Kesterson RA, Boston BA, Cone RD, Smith FJ, Campfield LA, Burn P, Lee F 1997 Targeted disruption of the melanocortin-4 receptor results in obesity in mice. Cell 88:131-141

Ishizuka T, Ernsberger P, Liu S, Bedol D, Lehman TM, Koletsky RJ, Friedman JE 1998 Phenotypic consequences of a nonsense mutation in the leptin receptor gene (fak) in obese spontaneously hypertensive Koletsky rats. J Nutrit 128:2299-2306

Itoh K, Imai K, Masuda T, et al. 2001 Association between blood pressure and insulin resistance in obese females during weight loss and weight rebound phenomena. Hypertens Res 24:481-487

Jackic JM, Clark K, Coleman E, et al. 2001 American College of Sports Medicine position stand on appropriate intervention strategies for weight loss and prevention of weight regain in adults. Med Sci Sports Exer 33:2145-2156

Jacobs DB, Sowers JR, Hmeidan A, Niyogi T, Simpson L, Standley PR 1993 Effects of weight reduction on cellular cation metabolism and vascular resistance. Hypertension 21:308-314

Kambham N, Markowitz GS, Valeri AM, et al. 2001 Obesity related glomerulopathy: an emerging epidemic. Kidney Intl 59:1498-1509

Kannel WB, Garrison RJ, Dannenberg AL 1993 Secular blood pressure trends in normotensive persons. Am Heart J 125:1154-1158

Kassab S, Kato T, Wilkins C, Chen R, Hall JE, Granger JP 1995 Renal denervation attenuates the sodium retention and hypertension associated with obesity. Hypertension 25:893-897

Keen HL, Brands MW, Smith MS Jr, Shek EW, Hall JE 1997 Inhibition of thromboxane synthesis attenuates insulin-hypertension in rats. Am J Hypertens 10:1125-1131

Kenchaiah S, Evans JC, Levy D, et al. 2002 Obesity and the risk of heart failure. N Engl J Med 347:305-313

Kissebah AH, Krakower GR 1994 Regional adiposity and morbidity. Physiol Rev 74:761-811

Konstantinides S, Schafer K, Loskutoff DJ 2001 The prothrombotic effects of leptin - possible implications for the risk of cardiovascular disease in obesity. Ann NY Acad Sci 947:134-141

Kuo J, Jones OB, Hall JE 2001 Inhibition of NO synthesis enhances chronic cardiovascular and renal actions of leptin. Hypertension 37:670-676

Laasko M, Edelman SV, Brechtel G, Baron AD 1990 Decreased effect of insulin to stimulate skeletal muscle blood flow in obese men. J Clin Invest 85:1844-1852 
Laimer M, Ebenbichler CF, Kaser S, Sandhofer A, Weiss H, Nehoda H, Aigner F, Patsch JR 2002 Markers of chronic inflammation and obesity: a prospective study on the reversibility of this association in middle-aged women undergoing weight loss by surgical intervention. Intl J Obes Relat Metab Disord 26(5):659-662

Landsberg L, Krieger DR 1989 Obesity, metabolism, and the sympathetic nervous system. Am J Hypertens 2:1255-1325

Lee GH, Proenca R, Montex JM, Carroll KM, Darvishzadeh JG, Lee J, Friedman JM 1996 Abnormal splicing of the leptin receptor in diabetic mice. Nature 379:632-635

Lembo G, Vecchione C, Fratta L, Marino G, Santic DD, Trimarco V, d'Amati G, Trimarro B 2000 Leptin induces direct vasodilation through distinct endothelial mechanisms. Diabetes 49:293-297

Levin ER, Gardner DG, Samson WK 1998 Natriuretic peptides. N Engl J Med 339:321-328

Licata G, Scaglione, Capuana G, Parrinello G, Divincenzo D, Mazzola G 1990 Hypertension in obese subjects: distinct hypertensive subgroup. J Hum Hypertens 4:37-41

Licata G, Scaglione R, Ganguzza A, Corrao S, Donatelli M, Parrinello G, Dichiara MA, Merlino G, Cecala MG 1994a Central obesity and hypertension: relationship between fasting serum insulin, plasma renin activity, and diastolic blood pressure in young obese subjects. Am J Hypertens 7:314-320

Licata G, Volpe M, Scaglione R, Rubattu S 1994b Salt-regulating hormones in young normotensive obese subjects: effects of saline load. Hypertension 23:I20-I24

Lip GYH, Gammage MD, Beevers DG 1994 Hypertension and the heart. Br Med Bull 18:193-197

Loredo JS, Ancoli-Israel S, Dimsdale JE 2001 Sleep quality and blood pressure dipping in obstructive sleep apnea. Am J Hypertens 14:887-892

Lu H, Duanmu Z, Houck C, Jen KL, Buison A, Dunbar JC 1998 Obesity due to high fat diet decreases the sympathetic nervous and cardiovascular responses to intracerebroventricular leptin in rats. Brain Res Bull 47:331-335

Lucas CP, Estigarribia JA, Darga LL, Reaven GM 1985 Insulin and blood pressure. Hypertension 7:702-706

Maack T 1992 Receptors of atrial natriuretic factor. Annu Rev Physiol 54:11-27

Maffei M, Halaas J, Ravussin E, Pratley RE, Lee GH 1995 Leptin levels in human and rodent: measurement of plasma leptin and Ob RNA in obese and weight-reduced subjects. Nature Med 1:1155-1161

Mansuo K, Mikami H, Ogihara T, Tuck ML 2000 Weight gain-induced blood pressure elevation. Hypertension 35:1135-1140

Maoz E, Shamiss A, Peleg E, Salzberg M, Rosenthal T 1992 The role of atrial natriuretic peptide in the natriuresis of fasting. J Hypertens 10:1041-1044

Mark AL, Correia M, Morgan DA, Shaffer RA, Haynes WG 1999a State-of-the-art-lecture: Obesity-induced hypertension: new concepts from the emerging biology of obesity. Hypertension 3:537-541

Mark AL, Shaffer RA, Correia ML, Morgan DA, Sigmund CD, Haynes WG 1999b Contrasting blood pressure effects of obesity in leptin-deficient ob/ob mice and agouti yellow mice. J Hypertens 17:1949-1953

Massiera F, Seydoux J, Geloen A, et al. 2001 Angiotensinogen-deficient mice exhibit impairment of diet-induced weight gain with alteration in adipose tissue development and increased locomotor activity. Endocrinology 142:5220-5225

Masuo K, Mikami H, Ogihara T, et al. 2001a Differences in mechanisms between weight loss-sensitive and -resistant blood pressure reduction in obese subjects. Hypertens Res 24:371-376

Masuo K, Mikami H, Ogihara T, et al. 2001b Weight reduction and pharmacologic treatment in obese hypertensives. Am J Hypertens 14:530-538 
Masuzaki H, Paterson J, Shinyama H, et al. 2001 A transgenic model of visceral obesity and the metabolic syndrome. Science 294:2166-2170

McAuley MA, Chen X, Westfall TC 1993 Central cardiovascular actions of neuropeptide Y. In: Colmers WF, Wahlestedt C, eds. The Biology of Neuropeptide Y and Related Peptides. Totowa, NJ: Humana Press; 389-418

McMahon FG, Fujioka K, Singh BN, et al. 2000 Efficacy and safety of sibutramine in obese white and African American patients with hypertension: a 1-year, double-blind, placebo-controlled, multicenter trial. Arch Intern Med 160:2185-2191

Melo LG, Veress AT, Chong CK, Pang SC, Flynn TG, Sonnenberg H 1998 Salt-sensitive hypertension in ANP knockout mice: potential role of abnormal plasma renin activity. Am J Physiol 274:R255-R261

Melo LG, Steinhelper ME, Pang SC, Tse Y, Ackermann U 2000 ANP in regulation of arterial pressure and fluid-electrolyte balance: lessons from genetic mouse models. Physiol Genom 3:45-58

Messerli FH, Christie B, DeCarvalho JG, Aristimuno GG, Suarez DH, Dreslinski GR, Frohlich ED 1981 Obesity and essential hypertension: hemodynamics, intravascular volume, sodium excretion and plasma renin activity. Arch Intern Med 141:81-85

Messerli FH, Sundgard-Riiske K, Reisin E, Frohlich ED, Dunn FG 1983 Dimorphic cardiac adaptation to obesity and arterial hypertension. Ann Intern Med 99:757-761

Mountjoy KG, Mortrud MT, Low MJ, Simerlay RB, Cone RD 1994 Localization of the melanocortin-4 receptor (MC4-R) in neuroendocrine and autonomic control segments of the brain. Mol Endocrinol 8:1298-1308

Nabro K, Agren G, Jonsson E, Naslund I, Sjostrom L, Peltonem M 2002 Pharmaceutical costs in obese individuals: comparison with a randomly selected population sample and long-term changes after conventional and surgical treatment: the SOS intervention study. Arch Intern Med 162(18):2061-2069

Nakano Y, Oshima T, Sasaki S, et al. 2001 Calorie restriction reduced blood pressure in obesity hypertensives by improvement of autonomic nerve activity and insulin sensitivity. J Cardiovasc Pharmacol 38(suppl 1):S69-S74

Nakao K, Ogawa Y, Suga S, Imura H 1992 Molecular biology and biochemistry of the natriuretic peptide system. I. Natriuretic peptides. J Hypertens 10:907-912

National Institutes of Health 1998 Clinical guidelines on the identification, evaluation, and treatment of overweight and obesity in adults: the evidence report. Bethesda, MD: National Heart, Lung, and Blood Institute in cooperation with The National Institute of Diabetes and Digestive and Kidney Diseases, NIH publication 98-4083

Nolan JJ, Beerdsen P, Ludvik B, Joyce M, Olefsky J 1994 Improvement in glucose tolerance and insulin resistance in obese subjects treated with troglitazone. N Engl J Med 331(18):11881193

Okosun ISA, Choi S, Dent MM, et al. 2001 Abdominal obesity defined as a larger than expected girth is associated with racial/ethnic differences in the risk of hypertension. J Hum Hypertens 15:307-312

Onions KL, Hunt SC, Rutkowski MP, Klanke CA, Su YR, Reif M, Menon AG 1998 Genetic markers at the leptin (ob) locus are not significantly linked to hypertension in African Americans. Hypertension 31:1230-1234

Pellymounter MA, Cullen MJ, Baker MB, Hecht R, Winters D, Boone T, Collins F 1995 Effects of the obese gene product on body weight regulation in ob/ob mice. Science 269:540-543

Rahmouni K, Haynes WG, Morgan DA, et al. 2001 Selective resistance to central administration of leptin in agouti mice. Hypertension 38:506 (abstract)

Reaven GM 1993 Role of insulin resistance in human disease (syndrome X): an expanded definition. Annu Rev Med 44:121-131 
Reaven GM, Hoffman BB 1987 A role for insulin in the etiology and course of hypertension. Lancet 2:435-437

Reisen E, Abel R, Modan M, Silverberg DS, Eliahou HE, Modan B 1978 Effect of weight loss without salt restriction on the reduction of blood pressure in overweight hypertensive patients. N Engl J Med 198:1-6

Reisin E, Messerli FH, Ventura HO, Frohlich ED 1984 Renal hemodynamics in obese and lean essential hypertensive patients. In: Messerli FH, ed. Kidney in Essential Hypertension. Boston: Martinus Nihoff; 125-129

Reisin E, Azars S, DeBoisblanc BP, et al. 1993 Low calorie unrestricted protein diet attenuates renal injury in hypertensive rats. Hypertension 21:971-974

Reisin E, Weir MR, Falkner B, et al. 1997 Lisinopril versus hydrochlorothiazide in obese hypertensive patients: a multicenter placebo-controlled trial: Treatment in Obese Patients with Hypertension (TROPHY) Study Group. Hypertension 30:140-145

Resnick LM, Militianu D, Cunnings AJ, Pipe JG, Evelhoch JL, Soulen RL 1997 Direct magnetic resonance determination of aortic distensibility in essential hypertension, relation to age, abdominal visceral fat, and in situ intracellular free magnesium. Hypertension 30:654-659

Ribstein J, du Cailar G, Mimran A 1995 Combined renal effects of overweight and hypertension. Hypertension 26:610-615

Rissanen P, Vahtera E, Krusius T, et al. 2001 Weight change and blood coagulability and fibrinolysis in healthy obese women. Intl J Obes Relat Metab Disord 25:212-218

Rocchini AP 2002 Obesity hypertension. Am J Hypertens 15:50S-52S

Rocchini AP, Moorehead C, Wentz E, Deremer S 1987 Obesity-induced hypertension in the dog. Hypertension 9:III64-III68

Rocchini AP, Katch V, Kveselis D, Moorehead C, Martin M, Lampman R, Gregory M 1989a Insulin and renal retention in obese adolescents. Hypertension 14:367-374

Rocchini AP, Key J, Bordie D, et al. 1989b The effect of weight loss on the sensitivity of blood pressure to sodium in obese adolescents. N Engl J Med 321:580-585

Rocchini AP, Moorehead C, DeRemer S, Goodfriend TL, Ball DL 1990 Hyperinsulinemia and the aldosterone and pressor responses to angiotensin II. Hypertension 15:861-866

Rocchini AP, Moorehead C, Katch V, Key J, Finta KM 1992 Forearm resistance vessel abnormalities and insulin resistance in obese adolescents. Hypertension 19:615-620

Rocchini A, Marker P, Cervenka T 1996 Time course of insulin resistance associated with weight gain in the dog: relationship to the development of hypertension. Am J Physiol 272:E147E154

Rocchini AP, Mao HZ, Babu K, Marker P, Rocchini AJ 1999 Clonidine prevents insulin resistance and hypertension in obese dogs. Hypertension 33:548-553

Rockstroph JK, Schmeider RE, Schachinger H, Messerli FH 1992 Stress response pattern in obesity and systemic hypertension. Am J Cardiol 31:1035-1039

Rosenzweig A, Seidnan CE 1991 Atrial natriuretic factor and related peptides hormones. Annu Rev Biochem 60:229-255

Rössner S, Sjöström L, Noack R, et al. 2000 Weight loss, weight maintenance, and improved cardiovascular risk factors after 2 years treatment with orlistat for obesity. Obes Res 8:49-61

Rumantir MS, Vaz M, Jennings GL, Collier G, Kaye DM, Seals DR, Wiesner GH, BrunnerLaRocca HP, Esler MD 1999 Neural mechanisms in human obesity-related hypertension. J Hypertens 17:1125-1133

Sakurai T 1999 Orexins and orexin receptors: implications in feeding behaviour. Regul Peptides 85:25-30

Sarzani R, Paci MV, Dessi-Fulgheri P, Espinosa E, Rappelli A 1993 A comparative analysis of atrial natriuretic peptide receptor expression on rat tissue. J Hypertens 11:S214-S216 
Sarzani R, Dessi-Fulgheri P, Paci MV, Espinosa E, Rappelli A 1996 Expression of natriuretic peptide receptors in human adipose and other tissues. J Endocrinol Invest 19:581-585

Sarzani R, Dessi-Fulgheri P, Salvi F, Serenelli M, Spagnolo D, Cola G, Pupita M, Giantomassi L, Rappelli A 1999 A novel promoter variant of the natriuretic peptide clearance receptor gene is associated with lower atrial natriuretic peptide and higher blood pressure in obese hypertensives. J Hypertens 17:1301-1305

Schmieder RE, Messerli FH 1993 Does obesity influence early target organ damage in hypertensive patients? Circulation 87:1482-1488

Schmieder RE, Gatzka C, Schachinger H, et al. 1993 Obesity as a determinant to antihypertensive treatment. Br Med J 307:537-540

Schorr U, Blaschke K, Turan S, Distler A, Sharma AM 1998 Relationship between angiotensinogen, leptin and blood pressure levels in young normotensive men. J Hypertens 16:1475-1480

Sechi LA 1999 Mechanisms of insulin resistance in rat models of hypertension and their relationships with salt sensitivity. J Hypertens 17:1229-1237

Seeley RJ, Yagaloff KA, Fisher SL, Burn P, Thiele TE, van Dijk G, Baskin DG, Schwartz MW 1997 Melanocortin receptors in leptin effects. Nature 390:349

Sharma AM, Pischon T, Hardt S, et al. 2001 Hypothesis: beta-adrenergic receptor blockers and weight gain: a systematic analysis. Hypertension 37:250-254

Shek EW, Brands MW, Hall JE 1998 Chronic leptin infusion increases arterial pressure. Hypertension 31:409-414

Shek EW, Kim PK, Hall JE 1999 Adrenergic blockade prevents leptin-induced hypertension. FASEB J 13:A456

Shirasaka T, Bnakazato M, Matsukura S, Takasaki M, Kannan H 1999 Sympathetic and cardiovascular actions of orexins in conscious rats. Am J Physiol 177:R1780-R1785

Simon G, Devereux RB, Roman MJ 1994 Relation of obesity and gender to left ventricular hypertrophy in normotensive and hypertensive adults. Hypertension 23:600-606

Sjostrom CD, Peltonem M, Sjostrom L 2001 Blood pressure and pulse pressure during long-term weight loss in the obese: the Swedish Obese Subjects (SOS) Intervention Study. Obes Res 9(3):188-195

Smith HL, Willius FA 1933 Adiposity of the heart. A clinical pathologic study of 136 obese patients. Arch Intern Med 52:910-931

Sowers JR 2001 Update on the cardiometabolic syndrome. Clin Cornerstone 4(2):17-23

Steinberg HO, Tarshoby M, Monestel R, Hook G, Cronin J, Johnson A, Bayazeed B, Baron AD 1997 Elevated circulating free fatty acid levels impair endothelium-dependent vasodilation. J Clin Invest 100:1230-1239

Stepniakowski KT, Goodfriend TL, Egan BM 1995 Fatty acids enhance vascular $\alpha$-adrenergic sensitivity. Hypertension 25:774-778

Stern JS, Gades MD, Wheeldon CM, et al. 2001 Calorie restriction in obesity: prevention of kidney disease in rodents. J Nutrit 131:913S-917S

Sugarman HJ, Windsor ACJ, Bessos MK, et al. 1997 Intra-abdominal pressure, sagittal abdominal diameter and obesity co-morbidity. J Intern Med 241:71-79

Sundquist J, Winkeby MA, Pudaric S 2001 Cardiovascular disease risk factors among older black, Mexican-American, and white women and men: an analysis of NHANES III, 1988-1994. J Am Geriatr Soc 49:109-116

Suter PM, Locher R, Häsler E, Vetter W 1998 Is there a role for the ob gene product leptin in essential hypertension? Am J Hypertens 11:1305-1311

Tan M, Chang S, Chang D, Tsai J CR, Lee Y 2003 Association of resistin gene $3^{\prime}$-untranslated region $+62 \mathrm{G} \rightarrow \mathrm{A}$ polymorphism with type 2 diabetes and hypertension in a Chinese population. J Clin Endocrinol Metab 88(3):1258-1263 
Terazi RC 1983 Hemodynamics of hypertension. In: Genest J et al., eds. Hypertension: Physiopathology and Treatment, chap 2. New York: McGraw-Hill; 15

Thornton JE, Chueng CC, Clifton DK, Steiner RA 1994 Regulation of hypothalamic proopiomelanocortin mRNA by leptin in ob/ob mice. Nature 372:425-432

Torgerson JS, Sjostrom L 2001 The Swedish Obese Subjects (SOS) study — rationale and results. Intl J Obes Relat Metab Disord 25:S2-S4

Tuck ML 1992 Obesity, the sympathetic nervous system, and essential hypertension. Hypertension 19:167-177

Tuck ML, Sowers J, Dornfield L, Kledzik G, Maxwell M 1981 The effect of weight reduction on blood pressure plasma renin activity and plasma aldosterone level in obese patients. N Engl J Med 304:930-933

Uckaya G, Ozata M, Sonmez A, Kinalp C, Eyileten T, Bingol N, Koc B, Kocabalkan F, Ozdemir IC 1999 Plasma leptin levels strongly correlate with plasma renin activity in patients with essential hypertension. Horm Metab Res 31:435-438

Umemura S, Nyui N, Tamura K, Hibi K, Yamaguchi S, Nakamaru M, Ishigami T, Yabana M, Kihara M, Inoue S, Ishii M 1997 Plasma angiotensinogen concentrations in obese patients. Am J Hypertens 10:629-633

U.S. Renal Data System 2001 USRDS 2001 annual data report: atlas of end-stage renal disease in the United States. Bethesda, MD: National Institutes of Health, National Institute of Diabetes and Digestive and Kidney Diseases

Vaisse C, Clement C, Guy-Grand B, Froquel P 1998 A frameshift mutation in human MC4R is associated with a dominant form of obesity. Nature Genet 20:113-114

Van Vliet BN, Hall JE, Mizelle HL, Montani J-P, Smith MJ Jr 1995 Reduced parasympathetic control of heart rate in obese dogs. Am J Physiol 269:H629-H637

VanHeek M, Comptom DS, France CF, Tedesco RP, Fawzi AB, Graziano MP, Sybertz EJ, Strader CD, Davis HR 1997 Diet-induced obese mice develop peripheral, but not central, resistance to leptin. J Clin Invest 99:385-390

Wadden TA, Berkowitz RI, Womble LG, Sarwer DB, Arnold ME, Steinberg CM 2000 Effects of sibutramine plus orlistat in obese women following 1 year of treatment by sibutramine alone: a placebo-controlled trial. Obes Res 8(6):431-437

Weir MR, Reisin E, Falkner B, Hutchinson HG, Sha L, Tuck ML 1998 Nocturnal reduction of blood pressure and the antihypertensive response to diuretic or angiotensin converting enzyme inhibitor in obese hypertensive patients. Am J Hypertens 11:914-920

Weisinger JR, Kempson RL, Eldridge L, et al. 1974 The nephrotic syndrome: a complication of massive obesity. Ann Intern Med 81:440-447

Wesson DE, Kurtzman NA, Prommer JP 1985 Massive obesity and nephrotic proteinuria with a normal renal biopsy. Nephron 40:235-237

Weyer C, Pratley RE, Snitker, Spraul M, Ravussin E, Tataranni PA 2000 Ethnic differences in insulinemia and sympathetic tone as links between obesity and blood pressure. Hypertension 36:531-537

Wilsgaard T, Schirmer H, Arnesen E 2000 Impact of body weight on blood pressure with a focus on sex differences: the Tromso Study, 1986-1995. Arch Intern Med 160(18):2847-2853

Wofford MR, Anderson DC, Brown CA, et al. 2001 Antihypertensive effect of alpha and beta adrenergic blockade in obese and lean hypertensive subjects. Am J Hypertens 14:694-698

Yeo GSH, Farooqi IS, Aminian S, Halsall DJ, Stanhope RE, O'Rahilly S 1998 A frameshift mutation in MC4R associated with dominantly inherited human obesity. Nature Genet 20:111-112

Yusuf S, Sleight P, Pogue J, et al. 2000 Effects of an angiotensin-converting-enzyme inhibitor, ramipril, on cardiovascular events in high-risk patients. N Engl J Med 342:145-153 
Zavoral JH 1998 Treatment with orlistat reduces cardiovascular risk in obese patients. J Hypertens 16:2013-2017

Zemel MB 1998 Nutritional and endocrine modulation of intracellular calcium: implications in obesity, insulin resistance and hypertension. Mol Cell Biochem 188:129-136

Zhang R, Reisin E 2000 Obesity-hypertension: the effects on cardiovascular and renal systems. Am J Hypertens 13:1308-1314

Zhjang Y, Proenca R, Maffei M, Barone M, Leopold L, Friedman JM 1994 Positional cloning of the mouse obese gene and its human homologue. Nature 372:425-432 